\title{
LEGITIMAÇÃO DISCURSIVA DOS DIREITOS HUMANOS
}

\author{
CARLOS ALEXANDRE DE AZEVEDO CAMPOS*
}

\begin{abstract}
RESUMO: No atual estágio do pensamento jurídico-filosófico, retomou-se a discussão sobre a legitimação do ordenamento jurídico e dos direitos humanos. A estratégia discursiva de legitimação dos direitos humanos se desenvolve no âmbito da virada pragmático-discursiva da linguagem e da construção habermasiana da ética do discurso, sendo a proposta teorética de Robert Alexy a que se tem apresentado como a mais bem desenvolvida de nosso tempo. A legitimação discursiva dos direitos fundamentais se realiza com o auxílio dos princípios formais, notadamente da ponderação, que pode servir tanto como ferramenta metodológica de solução de conflitos concretos, quanto como princípio de legitimação. Na verdade, a ponderação faz parte da própria estrutura do Direito.
\end{abstract}

PALAVRAS-CHAVES: Direitos Humanos; Legitimação Discursiva; Teoria do Discurso; Ponderação.

ABSTRACT: On the current stage of the legal-philosophical thought, retook itself the discussion about the legal order and human rights legitimation. The discoursive strategy of human rights legitimation advances in the extent of the language pragmatic-discoursive turn and habermasian discourse ethics, and Robert Alexy's theoretical proposition is the best developed of our age. The human rights discursive legitimation performs with the support of the formal principles, notedly balancing, that can serve as much methodological tool for actual conflicts solution, as legitimation principle. Indeed, balancing is a part of the very structure of Law.

KEYWORDS: Human Rights; Discoursive Legitimation; Discourse Theory; Balancing.

SUMÁRIO: Apresentação; I. Premissas Introdutórias; II. Legitimação Discursiva dos Direitos Humanos; III. Princípios de Legitimação e Ponderação; Conclusões; Bibliografia.

SUMMARY: Presentation; I. Preliminary Premises; II. Discoursive Legitimation of the Human Rights; III. Legitimation Principles and Balancing; Conclusions; Bibliography.

Artigo recebido em 18.02.2011. Pareceres emitidos em 04.03.2011 e 20.03.2011.

Artigo aceito para publicação em 12.04.2011.

* Mestrando em Direito Público da Universidade do Estado do Rio de Janeiro - UERJ. Professor de Direito Tributário da Universidade Candido Mendes - Campus Campos dos Goytacazes (RJ) 


\section{APRESENTAÇÃO}

\section{Delimitação do Tema}

Na presente quadra histórica da evolução do pensamento jurídico-filosófico, marcada por profundas transformações no modo de se compreender e aplicar o Direito, retoma-se a discussão sobre a legitimação do ordenamento jurídico e dos direitos fundamentais. ${ }^{1}$ Superada a ideia da coincidência entre legalidade e legitimidade, e com a reaproximação do Direito aos valores da liberdade e da justiça, que devem se harmonizar com a segurança e a democracia, cresce de importância a tarefa de busca da legitimação destes direitos.

O presente texto explora a legitimação dos direitos humanos ${ }^{2}$ por meio do discurso e com a intermediação dos princípios formais, notadamente da ponderação. Pretende-se demonstrar o que é a empreitada discursiva de legitimação dos direitos humanos, oferecendo para o debate a proposta teorético-discursiva de Robert Alexy, desenvolvida no âmbito da virada pragmático-discursiva da linguagem e da construção habermasiana da ética do discurso.

\section{Estrutura do Texto}

Dentro das propostas deste trabalho, tal como muito resumidas acima, estruturamos o presente texto da seguinte forma: na Parte I, lançamos ideias sobre a justificação e o papel dos direitos humanos que acompanham todo o restante do texto; na Parte II apresentamos a proposta teórica-discursiva de Robert Alexy como forma de identificação da esfera de fundamentalidade dos direitos. Nesta mesma parte tratamos do debate que o referido professor alemão travou com seu compatriota Klaus Günther acerca da teoria do discurso e a distinção entre discurso de legitimação e discurso de aplicação. A Parte III é dedicada aos princípios formais que cumprem papel decisivo no processo de legitimação dos direitos humanos, com destaque para o princípio da ponderação. Abordaremos a trajetória teórico-filosófica da ponderação, assim como as críticas que Ihe são dirigidas. Na Conclusão,

${ }^{1}$ TORRES, Ricardo Lobo. Introdução in TORRES, Ricardo Lobo (org.) Legitimação dos Direitos Humanos. 2. ed. Rio de Janeiro: Renovar, 2002, pp. 3/4.

${ }^{2}$ Não se ignora a importância de se evitar a imprecisão terminológica existente acerca da denominação destes direitos, em razão de ser notório que a presença de termos linguísticos precisos e coerentes se mostra sempre importante para o bom desenvolvimento de qualquer conhecimento científico, e especialmente para o conhecimento científico-jurídico, haja vista este ser construído sobre uma forma especial de linguagem: a linguagem jurídica. Consideramos adequada, para fins práticos, a distinção entre os termos "direitos humanos" e "direitos fundamentais" baseada em um critério jurídico-positivo que considera os direitos humanos como aqueles que são reconhecidos em fontes normativas internacionais (tratados internacionais) e os direitos fundamentais como os direitos reconhecidos em fontes normativas internas (constituições). Porém, para o propósito do presente texto, utilizaremos estes termos indistintamente, precisando-os segundo este critério jurídico-positivo apenas quando se mostrar imprescindível destacar que estamos nos referindo a direitos contidos em um texto constitucional ou em um tratado internacional. Sobre estas distinções terminológicas, cf.: PÉREZ LUÑO, Antonio-Enrique. Derechos Humanos, Estado de Derecho y Constitución. 9. ed. Madrid: Tecnos, 2005, pp. 31/40; SARLET, Ingo Wolfgang. A Eficácia dos Direitos Fundamentais. 7. ed. Porto Alegre: Livraria do Advogado, 2007, pp. 33/34. 
realizamos uma rápida síntese do que foi abordado, chamando a atenção uma vez mais, e novamente de modo incidental, para a importância do desenvolvimento de uma teoria da autoridade a acompanhar a estratégia discursiva de legitimação dos direitos humanos, de modo que este processo de justificação não se afaste das preocupações institucionais que também são uma marca do constitucionalismo contemporâneo.

\section{PREMISSAS INTRODUTÓRIAS}

\section{Justificação dos Direitos Humanos - direitos morais}

Dentre as diferentes e importantes abordagens de justificação dos direitos humanos, tais como a jusnaturalista (clássica, racionalista, ontológica, deontológica, etc.), a historicista, a contratualista, a institucionalista ${ }^{3}$, adotamos, sem deixar de considerar os mais pertinentes aportes teóricos destas formulações, a chamada justificação ética ou axiológica dos direitos humanos, ou seja, a ideia de que a origem e a justificação destes direitos não são jurídicas, no sentido de derivadas de uma positivação, mas anteriores ao jurídico. A justificação dos direitos humanos se obtém fora do ordenamento jurídico. O papel da positivação é o de reconhecimento e garantia destes direitos, o ponto de partida para a sua institucionalização, mas não o de sua criação e justificação. ${ }^{4}$

Positivados e judicializados, estes direitos adquirem um estágio de institucionalização importante ${ }^{5}$ para a sua promoção e efetivação. ${ }^{6}$ Estes direitos humanos, positivados em uma ordem jurídica internacional ou

\footnotetext{
${ }^{3}$ Sobre diferentes modos de justificação dos direitos humanos, cf. TORRES, Ricardo Lobo. A Legitimação dos Direitos Humanos e os Princípios da Ponderação e da Razoabilidade. In: TORRES, Ricardo Lobo (org.) Legitimação dos Direitos Humanos. 2. ed., Rio de Janeiro: Renovar, 2002, pp. 477/490; FERNANDEZ, Eusebio. Fundamento de los derechos humanos. In: Anuário de Derechos Humanos, vol. 1. Madrid: Universidad Complutense, 1981; CAMPOS, Germán J. Bidart. Teoría General de los derechos humanos. Buenos Aires: Astrea, 2006, pp. 85/93; PÉREZ LUÑO, Antonio Enrique. Derechos Humanos, Estado de Derecho y Constitución. 9. ed., Madrid: Tecnos, 2005, pp. 134/186: o autor distingue fundamentação objetiva, subjetiva e intersubjetiva; MacCORMICK, Neil. Institutions of Law. An Essay in Legal Theory. Oxford: Oxford University Press, 2007, pp. 271 e ss., onde o autor trata da faceta institucional dos direitos humanos.

${ }^{4}$ FERNANDEZ, Eusebio. Fundamento de los derechos humanos. In: Anuário de Derechos Humanos, vol. 1. Madrid: Universidad Complutense, 1981, p. 97: "A fundamentação ética ou axiológica dos direitos humanos fundamentais parte da tese de que a origem e fundamento destes direitos nunca pode ser jurídica senão prévia ao jurídico. O Direito (me refiro sempre ao Direito positivo) não cria os direitos humanos, seu notável labor, sem o qual o conceito de direitos humanos não terá plena efetividade, está em reconhecê-los, convertê-los em normas jurídicas e assegurá-los também jurídicamente".

${ }_{5}$ Robert Alexy fala em transformação necessária dos direitos humanos em direito positivo enquanto é necessário, de um modo geral, "ter direito positivo": ALEXY, Robert. Teoría del discurso y derechos humanos. Bogotá: UEC, 2001, p. 94.

${ }^{6}$ Amartya Sen apresenta uma postura cética quanto a confiar o potencial de efetividade dos direitos humanos apenas à legislação, destacando a importância do foco sobre a discussão pública para o reconhecimento, realização e avanço dos direitos humanos; cf. SEN, Amartya. Human rigths and the limits of the Law. Cardozo Law Review 27 (6), 2006, p. 2.916: “(..) direitos humanos são mais bem vistos como articulações de ética social".
} 
nacional (constitucional), justificar-se-iam em princípios morais ${ }^{7}$ prévios. Justificados sobre a base destes princípios morais, os direitos humanos são, em última análise, direitos morais ${ }^{8}$, de tal forma que os conflitos que envolvam estes direitos são, em última instância, conflitos morais.

2. Os Direitos Humanos são parâmetros de legitimação do Direito

Ao mesmo tempo em que se legitimam nos princípios morais, os direitos humanos legitimam a ordem jurídica. Habermas destaca que os direitos humanos têm "faces de Jano que se voltam simultaneamente para a Moral e para o Direito": justificam-se na moral e legitimam o ordenamento jurídico. ${ }^{9}$ Os direitos humanos seriam verdades morais, passíveis de justificação racional, que operam como fundamento de validade dos ordenamentos jurídicos. Em última análise, é o sistema de princípios morais que funcionaria como elemento de legitimação da própria ordem jurídica, e em primeiro plano (interno), da ordem constitucional. Uma adequada teoria sobre a legitimação dos direitos humanos deve então necessariamente observar estes dois pontos: os direitos humanos justificam-se em princípios morais e ao mesmo tempo legitimam a ordem jurídica. Apresenta-se então correta a tese alexyana de que toda norma jurídica, em alguma medida, deve satisfazer uma pretensão de correção moral. ${ }^{10}$

O Direito interage com a Moral por meio dos direitos humanos. A compreensão do Direito envolverá então, nas questões mais dramáticas sobre direitos, condicionantes morais, além de condicionantes puramente jurídico-positivas. Nestes casos, a avaliação da validade das práticas constitucionais e do próprio ordenamento jurídico consistirá, também e em maior ou menor medida, em julgamentos segundo parâmetros de conteúdo moral.

\section{Dilemas morais em sociedades complexas}

Cumpre ressaltar, porém, que estes princípios morais não estão definitivamente construídos em uma dada ordem moral preestabelecida a orientar uma institucionalização absolutamente satisfatória. Como adverte Rawls, as sociedades modernas possuem como uma de suas condições históricas e sociais o "fato do pluralismo razoável", onde cidadãos razoáveis possuem visões muito distintas, igualmente justificáveis em bases racionais,

\footnotetext{
${ }^{7}$ NINO, Carlos Santiago. La constitución de la democracia deliberativa. Barcelona: Gedisa, 2003, p. 73: "Os direitos constitucionais são em última instância direitos morais, já que derivam de princípios que têm as propriedades de autonomia, finalidade, superveniência, publicidade, universalidade e generalidade. Estas são as características distintivas dos princípios morais".

${ }^{8}$ NINO, Carlos Santiago. Introducción al Análisis del Derecho. 11. ed. Barcelona: Ariel, 2003, p. 417: "Os 'direitos individuais' são os direitos morais que os homens têm não por certa relação especial com outros homens, nem por ocupar determinado cargo ou função, nem por certas particularidades físicas ou intelectuais, nem pelas circunstâncias em que um indivíduo pode encontrar-se, senão pelo fato de ser homens."

${ }^{9}$ HABERMAS, Jürgen. Sobre a legitimação pelos Direitos Humanos. In: MERLE, Jean-Christophe; MOREIRA, Luiz (org.) Direito \& Legitimidade. São Paulo: Landy, 2003, p. 72.

${ }^{10}$ ALEXY, Robert. The Dual Nature of Law. Ratio Juris 23 (2), 2010, p. 171: "a pretensão de correção da norma sempre tem referência não apenas a fatos sociais, mas também à moralidade".
} 
sobre as escolhas essenciais para suas vidas. ${ }^{11}$ Com efeito, a afirmação dos princípios morais como justificação dos direitos humanos não se constrói a partir de ideias metafísicas, mas em ações humanas, em comportamentos humanos, de modo que justificado no contexto das práticas sociais, a dimensão humana destes princípios morais conduz inevitavelmente a certas "indeterminações morais", revelando um grau moderado de incompletude do sistema moral. Esta incompletude desborda na incidência de "desacordos morais razoáveis", que mais parecem "dilemas morais aparentemente insolúveis", em verdadeiros "empates morais"12.

Muitos conflitos tormentosos que envolvem direitos fundamentais são, em última análise, desacordos morais razoáveis, ou seja, conflitos entre os princípios morais que legitimam estes direitos colidentes e que não encontram na Constituição uma solução adequada, pronta e acabada, ou nem mesmo que possa ser deduzida sistemicamente. Dessa forma, os juízos que pretendem solucionar estes conflitos serão, inexoravelmente, juízos de desempate moral. Grandes questões contemporâneas, deixadas em aberto pelos constituintes locais, que podem ser denominadas, com Jeremy Waldron, de "questões de direitos "divisoras de águas"'13, são autênticos dilemas morais aparentemente insolúveis.

Estes desacordos morais são inevitáveis, pois o pluralismo razoável é uma condição permanente da cultura pública da democracia. As sociedades democráticas são sempre marcadas pela diversidade de doutrinas religiosas, filosóficas e morais ${ }^{14}$. Mas, se o pluralismo razoável é uma condição intrínseca da democracia, então os desacordos morais decorrentes só podem ser legitimamente resolvidos por procedimentos democráticos. E é neste ponto que ganha importância a legitimação pragmática ou discursiva dos direitos humanos. A validez destes juízos morais deverá ser afirmada discursivamente segundo a observância de condições procedimentais que asseguram a imparcialidade deste discurso, ou seja, que observem tanto a universalidade destes direitos quanto a autonomia (privada e pública) dos cidadãos. A construção destes juízos deve, portanto, ocorrer de forma democraticamente inclusiva.

No âmbito destes conflitos morais potenciais, não há que se falar em soluções apriorísticas, mas em acomodação das "oposições fundamentais" por meio de uma ponderação construída em um discurso de legitimação. ${ }^{15}$

${ }^{11}$ RAWLS, John. La justicia como equidad. Uma reformulación. Barcelona: Paidós, 2002, pp. 58/60. ${ }^{12}$ NINO, Carlos Santiago. Ética y derechos humanos. Um ensayo de fundamentación. 2. ed. Buenos Aires: Astrea, 2007, pp. 120/125.

${ }^{13}$ WALDRON, Jeremy. The Core of the Case Against Judicial Review. The Yale Law Journal 115 (6), 2006, p. 1.367.

${ }^{14}$ RAWLS, John. La justicia como equidad. Uma reformulación. Barcelona: Paidós, 2002, p. 60.

${ }^{15}$ TORRES, Ricardo Lobo. A Legitimação dos Direitos Humanos e os Princípios da Ponderação e da Razoabilidade. In: TORRES, Ricardo Lobo (org.) Legitimação dos Direitos Humanos. 2. ed., Rio de Janeiro: Renovar, 2002, p. 496; Idem. Da Ponderação de Interesses ao Princípio da Ponderação. In: ZILLES, Urbano (coord.). Miguel Reale. Estudos em homenagem a seus 90 anos. Porto Alegre: EDIPUCRS, 2000, p. 648: "A ideia de um princípio absoluto ou superior 
Sem embargo, a legitimação do Direito pelos direitos humanos, em sociedades plurais e complexas, não pode se realizar de modo estático, pré-determinado. Daí que, nos parece uma estratégia acertada apostar em uma dinâmica discursiva de legitimação. Significa dizer: principalmente nas questões mais dramáticas, nos autênticos "empates morais", apostamos que a legitimação discursiva dos direitos humanos serve de ferramenta adequada para a construção das soluções necessárias. ${ }^{16}$

\section{LEGITIMAÇÃO DISCURSIVA DOS DIREITOS HUMANOS}

\section{Legitimação, Justificação, Legitimidade e Fundamento}

Segundo Lobo Torres, "a legitimação do Estado e do ordenamento jurídico é o processo de julgamento de suas qualidades e de sua validade ética". ${ }^{17}$ Legitimação de uma proposição normativa ou de uma ação estatal, portanto, é a investigação acerca das razões a favor do seu status de correção, das suas razões corretas. É o processo por meio do qual se busca as respostas ao porquê da afirmação de correção dos direitos humanos, da dignidade humana, do controle de constitucionalidade, do federalismo, etc.

Legitimação e justificação são termos cambiantes, já legitimação e legitimidade se distinguem em razão da perspectiva dinâmica do primeiro em relação à perspectiva estática do segundo. Enquanto legitimação, como vimos, é um processo, uma atividade, legitimidade é uma condição ${ }^{18}$ a ser aferida por intermédio do próprio processo de legitimação: o que é legítimo só pode ser assim considerado depois de aprovado em um teste de legitimação; será legítimo porque se entendem devidamente justificadas as pretensões de validade. A legitimidade, segundo Lobo Torres, "se apóia no consenso sobre a adequação entre o ordenamento positivo e os valores", ao passo que a legitimação "consiste no próprio processo de justificação da Constituição e dos seus princípios fundamentais". ${ }^{19}$ Em suma, se legitimação é processo,

levaria à própria inconstitucionalidade do elenco desenhado no art. $1^{\mathrm{O}}$ ". Sobre a problemática do argumento de "inconstitucionalidade" apontado por Lobo Torres, cf. STF - Pleno ADI 815/RS. Rel. Min. MOREIRA ALVES, DJ 10/05/1996.

${ }^{16} \mathrm{O}$ professor neozelandês Jeremy Waldron destaca que temos corretamente reconhecido a importância de se pensar firme sobre a justiça e sobre o que ela exige em termos de distribuição de bens, estruturas e respeito por indivíduos e grupos, mas que, dada a inevitabilidade de desacordos sobre tudo isso, "uma teoria da justiça e dos direitos precisa ser complementada por uma teoria da autoridade". (WALDRON, Jeremy. A Right-Based Critique of Constitutional Rights. Oxford Journal of Legal Studies 13 (1), 1993, pp. 31/32). Com efeito, devemos investigar quem deve ter o poder de tomar decisões e por quais processos estas decisões devem ser tomadas. Em definitivo, e sem concordar com as conclusões, mas sim com as premissas de Waldron, os desacordos razoáveis requerem não só uma abordagem de justificação, mas também uma abordagem institucional de suas soluções. Não trataremos deste tema em nosso estudo, por extrapolar em muito nossas pretensões mais modestas.

${ }^{17}$ TORRES, Ricardo Lobo. A Legitimação dos Direitos Humanos e os Princípios da Ponderação e da Razoabilidade. In: TORRES, Ricardo Lobo (org.) Legitimação dos Direitos Humanos. 2. ed., Rio de Janeiro: Renovar, 2002, p. 468.

${ }_{18}$ D’ANREA, Luigi. Ragionevolezza e Legittimazione del Sistema. Milano: Giuffrè, 2005, pp. 318/319

${ }^{19}$ TORRES, Ricardo Lobo. A Legitimação dos Direitos Humanos e os Princípios da Ponderação e 
legitimidade é o resultado positivo que se pode alcançar por meio deste processo.

Por fim, legitimação diferencia-se de fundamentação na medida em que a primeira "exige sempre a procura de uma razão existente fora do sistema jurídico, o qual não pode se legitimar a si próprio" ${ }^{20}$, ao passo que o fundamento, "como causa, origem ou fonte" ${ }^{21}$, "pode ser coextensivo ao próprio objeto a se justificar: Estado, direitos, princípios, etc." ${ }^{22}$

\section{A renovada importância da legitimação dos direitos humanos}

A positivação dos direitos humanos, ao contrário do que vêm "afirmando os positivistas de diversos matizes" ${ }^{\prime 3}$, não supera a necessidade de sua justificação, nem tampouco afasta a preocupação com a sua garantia. A preocupação com a justificação dos direitos humanos justifica-se plenamente, e esta é uma das principais afirmações do movimento intitulado pós-positivismo. ${ }^{24}$ Os pós-positivistas "não ignoram a institucionalização do direito, porém o que interessa é o que está mais além dos limites estritamente institucionalizados". ${ }^{25} \mathrm{Um}$ metadiscurso de justificação ${ }^{26}$ dos direitos humanos representa então um necessário e legítimo contra-ataque às afirmações da espécie feita por Bobbio, no sentido de que não devemos nos preocupar com a justificação dos direitos, mas apenas com a sua efetivação. ${ }^{27}$

Com a afirmação do Estado democrático de direito e a reaproximação do Direito e da Moral, o tema da justificação dos direitos humanos e do

da Razoabilidade. In: TORRES, Ricardo Lobo (org.) Legitimação dos Direitos Humanos. 2. ed., Rio de Janeiro: Renovar, 2002, p. 468.

${ }^{20}$ TORRES, Ricardo Lobo. A Legitimação dos Direitos Humanos e os Princípios da Ponderação

e da Razoabilidade. In: TORRES, Ricardo Lobo (org.) Legitimação dos Direitos Humanos.

2. ed., Rio de Janeiro: Renovar, 2002, p. 470.

${ }_{21}$ Ibidem, p. 471

22 Ibidem, p. 474

${ }^{23}$ Ibidem, p. 467.

${ }^{24}$ BARROSO, Luís Roberto. Fundamentos Teóricos e Filosóficos do novo Direito Constitucional Brasileiro. In: Temas de Direito Constitucional. Tomo II. Rio de Janeiro: Renovar, 2003, p. 45: "O pós-positvismo identifica um conjunto de ideias difusas que ultrapassam o legalismo estrito do positivismo normativista, sem recorrer às razões subjetivas do jusnaturalismo. Sua marca é a ascensão dos valores, o reconhecimento da normatividade dos princípios e a essencialidade dos direitos fundamentais. Com ele, a discussão ética volta ao Direito".

${ }^{25}$ CALSAMIGLIA, Albert. Postpositivismo. Doxa 21 - I, 1998, p. 212.

${ }^{26}$ SILVA, Alexandre Garrido da. Direitos Humanos, Constituição e Discurso de Legitimação: Possibilidades e Limites da Teoria do Discurso. In: TORRES, Ricardo Lobo (org.) Legitimação dos Direitos Humanos. 2. ed., 2002, p. 45: "O metadiscurso de legitimação dos direitos humanos e fundamentais investiga a viabilidade teórica e as conseqüências práticas do empreendimento filosófico de justificação de tais direitos".

${ }^{27}$ BOBBIO, Norberto. Presente y porvenir de los derechos humanos. In: Anuário de Derechos Humanos, vol. 1. Madrid: Universidad Complutense, 1981, p. 9: "Em 1964, no Encontro promovido pelo 'Institut International de Philosophie' sobre o 'fundamento dos direitos humanos', tive ocasião de dizer em tom um tanto peremptório, ao final de minha conferência, que o problema grave de nosso tempo em relação aos direitos humanos não era o de fundamentá-los, senão o de protegê-los. Desde então não tenho tido porque mudar de opinião". 
próprio ordenamento jurídico ganhou força ${ }^{28}$. Voltou-se à discussão sobre a legitimação, ao lado da eficácia, dos direitos humanos e dos próprios ordenamentos jurídicos. Os direitos, as ações estatais e a própria ordem jurídica não devem mais ser justificados apenas sob uma perspectiva puramente interna, por meio de uma atividade estéril de autorreferência. A legitimação deve ser buscada fora do ordenamento jurídico, de modo que possamos compreender, por exemplo, o porquê dos direitos humanos ingressarem na vida do Estado e da sociedade gozando do status de jusfundamentalidade que lhes é próprio. ${ }^{29}$

Prova maior da importância do discurso de legitimação está, por exemplo, em sua utilidade para resolver o mais tormentoso desafio prático aos direitos humanos na atualidade, qual seja, o de conciliar a pretensão de universalidade dos direitos humanos e a exigência de um mínimo moral com as particularidades culturais de cada comunidade, muitas vezes marcadas por práticas incomuns para a maior parte das sociedades. Esta tarefa de conciliação não se realizará sem um esforço hercúleo de justificação e acomodação entre a pretensão de universalidade dos diretos humanos e o direito de autodeterminação cultural dos povos. Cumpre então a construção de um modelo adequado de legitimação dos direitos humanos que viabilize a acomodação racional, justa e inclusiva destes valores.

No presente texto, defendemos o modelo de legitimação que pensamos possuir viabilidade teórica e capacidade de minimizar as dificuldades advindas das complexidades sociais de nosso tempo: a legitimação pragmática ou discursiva dos direitos humanos e fundamentais. Segundo este modelo, a justificação dos direitos deve ser realizada de forma dialógica e com a intermediação dos princípios de legitimação, como o são os princípios da ponderação, da proporcionalidade, da razoabilidade, da igualdade, da coerência e da transparência. Os direitos fundamentais, diante do pluralismo de valores das sociedades complexas e do ideal democrático de autogoverno, vão se legitimar dialógica e discursivamente, i.e., argumentativamente. É o que se passa a abordar.

\footnotetext{
${ }^{28}$ TORRES, Ricardo Lobo. A Legitimação dos Direitos Humanos e os Princípios da Ponderação e da Razoabilidade. In: TORRES, Ricardo Lobo (org.) Legitimação dos Direitos Humanos. 2. ed., Rio de Janeiro: Renovar, 2002, p. 467; HABERMAS, Jürgen. Sobre a legitimação pelos Direitos Humanos. In: MERLE, Jean-Christophe; MOREIRA, Luiz (org.) Direito \& Legitimidade. São Paulo: Landy, 2003, p. 68: "É que o Direito não somente exige aceitação; não apenas solicita dos seus endereçados reconhecimento de fato, mas também pleiteia merecer reconhecimento". Em outra passagem (p. 69): "deve ser possível cumprir normas jurídicas, não porque obrigam, mas porque são legítimas".

${ }^{29}$ Os textos constitucionais e internacionais de direitos humanos são, segundo arguta lição de Nino, "objeto de justificação no primeiro estágio" segundo a "base de razões autônomas, que são, ao final das contas, princípios morais", e "base para a justificação de ações e decisões concretas no segundo estágio". (NINO, Carlos Santiago. La constitución de la democracia deliberativa. Barcelona: Gedisa, 2003, p. 70). Assim, a argumentação jurídica de justificação abre-se para um discurso de justificação pautado em princípios morais.
} 


\section{Legitimação Discursiva (Pragmática) e Argumentação Jurídica}

\subsection{Aspectos conceituais}

Legitimação pragmática dos direitos fundamentais é o empreendimento de justificação racional e universalista destes direitos por meio de um discurso aberto aos argumentos morais, e que se desenvolve com a intermediação dos princípios formais da ponderação, da razoabilidade, da igualdade, da transparência e da coerência. É a legitimação alcançada pelo discurso, por meio da força da argumentação; enfim, através do uso da função pragmático-discursiva - transformadora da realidade - da linguagem, que é associada aos movimentos filosóficos de resgate da razão prática e da virada pragmático-linguística.

Em sociedades complexas e pluralistas, diferentes pretensões de validade, igualmente merecedoras de respeito e consideração, concorrem entre si, de modo que diferentes fatores de legitimação operam em um sentido ou no outro. Daí ser necessário um esforço de reconstrução destes fatores de forma a acomodá-los em suas pretensões de validade. Este esforço de legitimação, no atual estágio filosófico pós-positivista, segundo defendido neste texto, deve ser realizado procedimentalmente por meio do discurso, ou seja, por meio de uma empreitada pragmático-linguística. Com efeito, é por meio da "função discursiva da linguagem" que se avaliará se uma determinada pretensão de correção é satisfeita. O processo de justificação de uma pretensão de correção ou validade moral se dará então com o julgamento dos melhores argumentos lançados em um discurso imparcial.

Daí porque o uso do termo legitimação pragmática ou discursiva: o processo de legitimação se opera por meio do discurso segundo a concepção pragmático-discursiva da linguagem, de modo que os direitos e o ordenamento vão encontrar sua legitimação no âmbito de um discurso jurídico aberto aos argumentos morais e condicionado por regras que assegurem a imparcialidade da participação na empreitada discursiva.

Esta estratégia teórica pretende responder aos questionamentos acerca da viabilidade teórica da legitimação dos direitos fundamentais por meio de uma construção que aposta na justificação da validade dos direitos por meio de um procedimento argumentativo. A proposta de legitimação pragmática dos direitos está então vinculada à teoria do discurso. Neste trabalho, vamos destacar a teoria do discurso de Robert Alexy tal como desenvolvida como proposta teorético-discursiva da legitimação dos direitos fundamentais. Mas antes da teoria alexyana, se mostra interessante o exame da base filosófica da proposta.

3.2. A base filosófica da Legitimação Pragmática - a virada linguística e o resgate da razão prática

Como dito, a legitimação pragmática é vinculada aos movimentos filosóficos da reabilitação da razão prática e da virada linguístico-pragmática. A reabilitação da razão prática, inserida no novo marco filosófico do pós-positivismo, consiste na superação do uso teórico da razão - o conhecimento pelo conhecimento, o 
saber em si - pelo uso prático da razão - o conhecimento como ação dirigida a transformar o real, o conhecimento normativo, diretivo ou regulador do agir humano. ${ }^{30}$ É o uso da razão para a solução de problemas práticos.

Por sua vez, a virada linguístico-pragmática é uma nova orientação da filosofia pós-positivista contemporânea que possibilita a reabilitação da razão prática sobre bases não-metafísicas, de modo que o pós-positivismo, "ao fazer a virada linguístico-pragmática", comprometeu-se "com uma filosofia pós-metafísica. ${ }^{31}$ Passou-se de uma filosofia transcendental do sujeito ou da consciência para uma filosofia da linguagem ou da intersubjetividade. É uma nova visão sobre a linguagem e sua centralidade para o pensamento em geral, onde esta passa a ser considerada, prioritariamente, uma atividade capaz de moldar a realidade e não simplesmente uma representação de fatos e coisas. A linguagem deixa de cumprir uma função meramente expressiva, simbolista, para tornar-se uma ação transformadora da realidade. A linguagem deixa de ser meramente descritiva ou representativa da realidade, e passa a ser uma forma de ação (pragmática), a ter uma dimensão comunicativa voltada para o agir prático, abrindo um espaço público entre falante e ouvinte. ${ }^{32}$ Daí que, tomando a linguagem como ação, pode-se falar em uma concepção pragmática da linguagem.

$\mathrm{Na}$ atualidade, a mais influente leitura destes movimentos filosóficos é aquela feita pela construção teórica do discurso habermasiano. Em Habermas, apostando na função pragmático-discursiva da linguagem, a razão prática ganhou a configuração de razão comunicativa, fundada na qualidade ética das práticas discursivas e na confiança no poder persuasivo dos melhores argumentos. Habermas, em seu projeto crítico ao Estado, vai se opor ao processo de exclusão da tematização dos fundamentos do poder que gera a despolitização das massas, com o "esvaziamento da atividade política cotidiana da cidadania em todas as instâncias da sociedade". ${ }^{33}$ O filósofo alemão lança-se a formular uma teoria da ação comunicativa, voltada à emancipação da cidadania e a libertação do homem das situações de alienação e despolitização: os homens deveriam participar da gestação comunicativa do poder. Habermas propõe então a assunção do poder político pela própria cidadania. ${ }^{34}$

Com sua Teoria da Ação Comunicativa, Habermas buscou formular bases normativas de uma teoria social crítica, pautadas em imperativos categóricos ampliados de inspiração kantiana, com o objetivo de demonstrar que os atores sociais devem se engajar em um permanente diálogo acerca

\footnotetext{
${ }^{30}$ BONALDO, Frederico; BENEDUZI, Renato Resende. Razão Prática e Razão Teórica. (verbete) In: BARRETO, Vicente de Paulo. Dicionário de Filosofia do Direito. Rio de Janeiro: Renovar, 2006, p. 693.

${ }^{31}$ NIGRO, Rachel. A virada linguístico-pragmática e o pós-positivismo. Direito, Estado e Sociedade n. 34, 2009, p. 170.

32 Ibidem, p. 187.

${ }^{33}$ LEAL, Rogério Gesta. Jürgen Habermas. (verbete) In: BARRETO, Vicente de Paulo. Dicionário de Filosofia do Direito. Rio de Janeiro: Renovar, 2006, p. 405.

${ }^{34}$ Ibidem, pp. 405/406.
} 
das razões de justificação de suas proposições argumentativas. Estas proposições argumentativas possuem pretensões de validade que devem ser problematizadas e satisfeitas sob condições de discurso.

Sob esta ótica, o processo de justificação ou legitimação das pretensões de validade problematizadas deve se desenvolver discursivamente, segundo regras procedimentais e a capacidade de cada um refletir e chegar a um entendimento mútuo (consenso). Habermas buscou a reconstrução dos pressupostos morais universais das práticas comunicativas e intersubjetivas, e com isso propôs a justificação da validade do ordenamento jurídico a partir de uma ética do discurso, superando o caráter monológico e o modelo metafísico de justificação da moralidade.

A fim de assegurar a imparcialidade no discurso, Habermas prescreve kantianamente que todo indivíduo deve ter igual oportunidade para articular, livre de qualquer constrangimento, suas opiniões, interesses e reclamações através do discurso prático em favor do consenso. Segundo sua construção teórica, a validade das normas depende da condição de seus destinatários poderem concordar com as mesmas como participantes do discurso. Este é o conteúdo do princípio do discurso, que prescreve, como fundamento da ética discursiva, que interesses não universalizáveis não podem servir de justificação de normas, pois "as únicas normas que têm o direito a reclamar validade são aquelas que podem obter a anuência de todos os participantes envolvidos num discurso prático". ${ }^{35}$

A validade seria então legitimada procedimentalmente, como um consenso livre sobre os argumentos problematizados discursivamente. Trata-se de uma teoria pós-metafísica da justiça porque fundada no reconhecimento discursivo de pretensões de validade. Com Habermas, a legalidade deverá extrair sua legitimidade de uma racionalidade procedimental com teor moral, e esta racionalidade resultará da institucionalização dos processos de argumentação moral - do discurso ${ }^{36}$. Por meio do discurso e da argumentação, questões práticas que envolvem o sistema de direitos podem ser julgados e decididos de modo imparcial e racional.

Trata-se então de uma teoria do discurso com bases normativas, que cumpre um papel fundamental nas relações entre Direito e Sociedade e na defesa de um modelo procedimental de democracia. Sobre esta base, Habermas procurou reconstruir o sistema de direitos e avaliar os espaços públicos de atuação das instituições como o Legislativo e a Jurisdição Constitucional. Em suma, a partir da teoria do discurso, Habermas enfrentou a problemática da legitimação do Direito e dos direitos, e as relações entre Direito, Moral e Política: ele propõe uma concepção da moral, do sistema de direitos e da democracia ancorada em sua teoria do discurso, e com o

\footnotetext{
${ }^{35}$ HABERMAS, Jürgen. Comentários à Ética do Discurso. Lisboa: Instituto Piaget, 1999, p. 16.

${ }^{36}$ HABERMAS, Jürgen. Facticidad y Validez. 4. ed., Madrid: Trotta, 2005, pp. 173/174. 
discurso procura fortalecer tanto a autonomia privada do indivíduo como a autonomia pública do cidadão. ${ }^{37}$

A teoria do discurso habermasiana é definitivamente uma defesa da democracia. O processo democrático deve institucionalizar os discursos e as negociações, de modo que aqueles que se engajam no discurso e na busca do consenso sejam efetivos participantes da governança pública, da criação e da aplicação do direito. ${ }^{38}$ Esta racionalidade procedimental discursiva deve governar tanto o processo de criação (discurso de legitimação) quanto o processo de aplicação (discurso de aplicação) do Direito, de forma a assegurar a imparcialidade destes processos como exigência do Estado democrático de direito. ${ }^{39}$

\subsection{A Teoria da Argumentação Jurídica de Robert Alexy}

Robert Alexy, na linha habermasiana, defende a legitimação dos direitos humanos através de práticas argumentativas, isto é, através do discurso. Sua teoria da argumentação jurídica busca demonstrar como é possível decisões jurídicas serem racionalmente fundamentadas. Portanto, sua teoria volta-se para a definição de critérios que permitam o controle da racionalidade das valorações feitas pelo autor da decisão jurídica, afirmando ser possível fundamentar racionalmente decisões jurídicas valorativas. Para tanto, Alexy desenvolveu uma teoria do discurso prático geral como base para a sua teoria da argumentação jurídica, defendendo que o controle das razões da decisão jurídica é um controle sobre os juízos práticos gerais, juízos abertos às razões pragmáticas, éticas e morais, de modo que a argumentação jurídica seria assim um caso especial do discurso prático geral. Na teoria de Alexy, portanto, a racionalidade da argumentação jurídica está vinculada à possibilidade de fundamentação racional dos juízos práticos em geral.

\subsubsection{O discurso prático racional geral}

O procedimento do discurso prático geral é um procedimento de argumentação ${ }^{40}$, de julgamento da validade das pretensões de correção moral das posições normativas assumidas no discurso, onde a racionalidade argumentativa é assegurada por regras procedimentais que governam 0 discurso ${ }^{41}$. $\mathrm{O}$ discurso prático geral seria então uma empreitada linguísticodialógica, governada por regras de procedimentos argumentativos, com a finalidade de julgar a correção prática de enunciados normativos. A validade universal de normas dialogicamente propostas dependeria, ainda que não exclusivamente, da observância destas regras procedimentais, do que decorre poder afirmar que Alexy propõe uma teoria procedimental da justiça.

\footnotetext{
${ }^{37}$ HABERMAS, Jürgen. Facticidad y Validez. 4. ed., Madrid: Trotta, 2005, p. 169.

${ }^{38}$ Ibidem, p. 169.

39 Ibidem, p. 174.

${ }^{40}$ ALEXY, Robert. Teoría del discurso y derechos humanos. Bogotá: UEC, 2001, p. 66.

41 Ibidem, p. 67: "Um discurso prático é racional na medida em que nele se preenchem as condições da argumentação prática racional. As condições de argumentação prática racional podem resumir-se em um sistema de regras do discurso".
} 
Alexy desenvolve uma versão teorético-discursiva da concepção kantiana da razão prática ${ }^{42}$. Influenciado pelo pensamento moral kantiano, portanto, orientado pela ideia de universalizabilidade que forma a base da concepção kantiana da razão prática ${ }^{43}$, Robert Alexy procura formular uma estratégia de legitimação dos direitos humanos por meio de um modelo de argumentação compatível com o Estado constitucional e democrático de direito. Assim, além de procedimental, Alexy propõe uma teoria liberal de legitimação dos direitos ${ }^{44}$.

Partindo da ideia de ética discursiva de Habermas, Alexy formula regras específicas que governam o discurso prático e que assim garantem a sua racionalidade e imparcialidade. Os juízos morais só podem alcançar o status de universalmente válidos por meio do discurso se forem observadas estas regras procedimentais discursivas. A teoria do discurso em Alexy, segundo estas condicionantes, configura-se também como uma teoria processual da correção prática. ${ }^{45}$

Estas regras procedimentais, embora não determinem o que deve ser tomado como base para a decisão e nem prescrevam todos os passos a serem seguidos, devem se apresentar como racionalmente suficientes para garantir um ambiente de liberdade e igualdade no discurso. Com efeito, estas regras expressam, ao nível da argumentação, as ideias liberais da universalidade e autonomia $^{46}$, e assim garantem o direito de cada um participar no discurso como sujeitos livres e iguais (liberdade e igualdade no discurso), ${ }^{47}$ podendo, estes participantes no discurso, exteriorizar, introduzir e questionar critérios, desejos e necessidades, bem como exercer a defesa deste direito de participação livre e igual quando, dentro ou fora do discurso, predomine a força. Em assegurarem a participação livre e igual de todos no discurso prático, estas regras constituem as condições de racionalidade da argumentação ${ }^{48} \mathrm{e}$ põem de manifesto o caráter universalista da teoria do discurso e sua correspondência aos princípios básicos do Estado democrático de direito.

Mas o discurso prático geral encontra limites, especialmente no que tange à falta de definitividade para certas questões controvertidas e à insegurança no cumprimento das decisões alcançadas. Estes limites do discurso prático

${ }^{42}$ ALEXY, Robert. A Discourse-Theoretical Conception of Pratical Reason. Ratio Juris 5 (3), 1992, p. 234.

${ }^{43}$ Ibidem, p. 234: "The idea of universalisability forms the basis of every Kantian conception of pratical rationality".

${ }^{44}$ ALEXY, Robert. Teoría del discurso y derechos humanos. Bogotá: UEC, 2001, p. 63: "A combinação das ideias de universalidade e de autonomia conduz a uma teoria política liberal. A concepção kantiana dos direitos humanos é uma concepção liberal dos direitos humanos".

45 Ibidem, p. 66.

${ }^{46}$ Ibidem, p. 68.

${ }^{47}$ Ibidem, p. 50

${ }^{48}$ Ibidem, p. 50: as principais regras são: "1. Todo aquele que pode falar, pode tomar parte no discurso. 2.a. Todos podem questionar qualquer afirmação. b. Todos podem introduzir qualquer ponto de vista no discurso. c. Todos podem exteriorizar seus critérios, desejos e necessidades. 3. Nenhum falante pode ser impedido de exercer a salvaguarda de seus direitos fixados em (1) e (2), quando dentro ou fora do discurso predomine a força." 
geral fundamentam a necessidade de regras jurídicas e com isso se dá o passo ao discurso jurídico, que igualmente permanecerá aberto às razões pragmáticas, éticas e morais, ou seja, à razão prática, mas sofrerão os limites impostos e gozarão das vantagens proporcionadas pela positivação. ${ }^{49}$

3.3.2. A institucionalização da razão prática: a necessidade do Direito

As regras tratadas até aqui se referem à esfera da fala, e não à esfera da ação. ${ }^{50}$ As regras procedimentais do discurso prático geral asseguram apenas a liberdade e a igualdade de participação no discurso, mas isso não significa que o resultado da deliberação será seguido por todos, com a liberdade e a igualdade presentes no discurso sendo transportadas para o campo da ação. Ademais, o amplo campo do que é discursivamente possível no discurso prático geral sugere a criação de restrições em favor da própria resolutividade da discussão.

Segundo Alexy, três são os problemas que conduzem à necessidade da positivação ${ }^{51}$ : (i) o problema do conhecimento, que diz com não ser possível o discurso prático geral, mesmo com o sistema de regras da fala, oferecer um procedimento que permita, em um número limitado de operações, alcançar sempre um resultado demasiado exato ${ }^{52}$; (ii) o problema da execução, que decorreria do fato do reconhecimento da correção moral ou legitimidade da norma não ser garantia de seu cumprimento; e (iii) o problema da organização, que requer adicionar à teoria de legitimação moral dos direitos pelo discurso uma teoria da autoridade do Direito positivo. ${ }^{53}$

Surge então a necessidade de sairmos do discurso prático geral para o discurso jurídico, de institucionalizarmos a razão prática. Como realisticamente reconhece Alexy, a transformação dos direitos humanos em Direito positivo é necessária como é, de um modo geral, necessário o Direito positivo ${ }^{54}$, algo como derivado de "exigências morais de evitar os custos da anarquia e da guerra civil e de alcançar as vantagens da coordenação e cooperação sociais." ${ }^{\text {"S }}$ Segundo Alexy, os direitos humanos, para desenvolverem todo o seu vigor, portanto, se realizarem no campo da ação, precisam ser reconhecidos

\footnotetext{
49 ALEXY, Robert. Teoria de la argumentación jurídica. 2. ed. Madrid: CEPC, 2007, p. 202: "Os limites do discurso prático geral fundamentam a necessidade de regras jurídicas. Com isso se produz o passo ao discurso jurídico".

${ }_{50}$ ALEXY, Robert. Teoría del discurso y derechos humanos. Bogotá: UEC, 2001, p. 93.

51 Ibidem, p. 94

52 Ibidem, pp. 51/52; Idem, Teoria de la argumentación jurídica. 2. ed. Madrid: CEPC, 2007, pp. 37/38: "E verdade que (as regras do discurso) não podem produzir nenhuma certeza definitiva no âmbito do discursivamente possível, porém são de enorme importância como explicação da pretensão de correção, como critério da correção de enunciados normativos, como instrumento de crítica de fundamentações não racionais, e também como precisão de um ideal ao qual se aspira".

${ }^{53}$ ALEXY, Robert. The Dual Nature of Law. ob.cit., p. 173: "A insuficiência da dimensão ideal como procedimento de decisão necessita como seu complemento a existência da dimensão real, ou seja, da dimensão positiva do direito."

${ }^{54}$ Cf. nota 4.

${ }^{55}$ ALEXY, Robert. The Dual Nature of Law. Ratio Juris 23 (2), 2010, p. 173.
} 
em Direito positivo, ou seja, serem transformados em Direito positivo. ${ }^{56}$

Essa necessidade de conexão dos elementos ideais da ordem normativa com elementos institucionais ou reais ${ }^{57}$, de passagem do estágio definido exclusivamente pelos ideais de correção e discurso para o estágio de regulação legal do procedimento, é o fundamento para Alexy defender que o discurso jurídico é um caso especial do discurso prático geral.

Contudo, a discussão não pode se limitar à forma de institucionalização do discurso prático geral em discurso jurídico. À questão de forma deve ser agregado o problema do conteúdo. Enquanto em relação à forma se discute como se dá a institucionalização dos direitos, em relação ao conteúdo se discute quais direitos podem ser justificados como fundamentais. É neste momento que se define uma estratégia substancial de legitimação dos direitos humanos segundo uma teoria discursiva. É o momento da definição dos critérios de legitimação teorético-discursiva dos direitos humanos e é do que se passa a tratar.

\subsubsection{A estratégia de legitimação dos direitos humanos segundo a} teoria do discurso

Alexy defende dois tipos diferentes de fundamentação ${ }^{58}$ teorético-discursiva dos direitos humanos: a direta e a indireta.

A fundamentação direta tem lugar com direitos justificados diretamente sobre a base da teoria do discurso, de tal forma que sem estes direitos não há que se falar em discurso; são os direitos discursivamente necessários em sentido estrito, cuja observância não estaria disponível às decisões políticomajoritárias, sendo sua não-validez discursivamente impossível. ${ }^{59}$

$\mathrm{Na}$ outra ponta, tem-se uma fundamentação "apenas indireta quando a decisão acerca dos direitos humanos se deixa a um processo político celebrado de fato, porém ao qual podem bastar determinadas exigências fundadas teorético-discursivamente. Se são satisfeitas estas exigências, então as decisões logradas nesse processo político sobre direitos humanos são legítimas e estes direitos, em consequência, indiretamente fundados teorético-discursivamente". ${ }^{60}$ Diferente dos direitos diretamente fundados, os direitos indiretamente fundados, longe de serem discursivamente impossíveis, não são discursivamente necessários em sentido estrito, mas apenas discursivamente possíveis. Fica evidente então que o conteúdo definitivo e a eficácia destes direitos dependem em grande medida das decisões políticomajoritárias de cada tempo. Assim, os direitos indiretamente justificados podem sofrer restrições por meio do processo democrático, ao passo que os direitos

\footnotetext{
${ }^{56}$ ALEXY, Robert. Teoría del discurso y derechos humanos. Bogotá: UEC, 2001, p. 93

57 Ibidem, p. 52

${ }^{58}$ Alexy utiliza os termos fundamentação e justificação como sinônimos: ALEXY, Robert. Teoria de la argumentación jurídica. 2. ed. Madrid: CEPC, 2007, p. 52, nota de rodapé 3, e p. 213, nota de rodapé 23.

${ }^{59}$ ALEXY, Robert. Teoría del discurso y derechos humanos. Bogotá: UEC, 2001, p. 97.

${ }^{60}$ ALEXY, Robert. Teoría del discurso y derechos humanos. Bogotá: UEC, 2001, p. 97.
} 
diretamente fundados correspondem ao núcleo essencial dos direitos humanos.

O grande desafio da teoria do discurso é então a definição de critérios seguros para afirmação de quais direitos são direta ou indiretamente fundados, o que envolve, por lógico, a grande tarefa empreendida por Alexy: definir como podem fundar-se os direitos humanos diretamente sobre a base da teoria do discurso.

Alexy nega que seja possível uma dedução dos direitos humanos diretamente das regras do discurso, pois ater-se a elas significaria apenas que "aos outros no discurso se dá o trato de interlocutores com os mesmos direitos", o que não significa que isto também ocorrerá na esfera da ação. Segundo o professor alemão, do reconhecimento pragmático-linquístico não segue ainda o reconhecimento moral ou jurídico. Seriam ainda necessárias premissas adicionais, igualmente pertencentes à teoria do discurso. ${ }^{61}$

O professor alemão apresenta três classes de fundamentação teoréticodiscursiva direta dos direitos humanos, que se encontram em relação de recíproca complementação e fortalecimento: a) o argumento da autonomia; b) o argumento do consenso; e c) o argumento da democracia.

\section{a) $\mathrm{O}$ argumento da autonomia}

Entendendo o conceito de "participação séria no discurso" como a participação dirigida a resolver conflitos sociais através de consensos discursivamente elaborados e controlados, no sentido de poder - o consenso - a todo momento ser novamente questionado, Alexy define que o argumento da autonomia requer que aquele que toma parte seriamente no discurso pressuponha a autonomia de seu interlocutor, ou seja, "aceite o direito de seu interlocutor a orientar sua conduta só em princípios que, depois de suficiente reflexão, se julguem corretos e em consequência válidos". ${ }^{62}$ Alexy acredita que com o argumento da autonomia se elimina a separação entre a ação e o discurso, sendo transmitidas "a liberdade e igualdade no discurso também à esfera da ação", de modo a poder-se afirmar que discurso e autonomia tornam-se dois lados da mesma moeda. ${ }^{63}$

Importante destacar aqui o argumento de Robert Alexy, que favorece uma abordagem dialógica como modelo adequado de legitimação de ações institucionais, no sentido de somente a possibilidade constante de revisar discursivamente todas as normas de ação sobre a base da autonomia ser capaz de elidir persistentes erros morais. Quem se engaja em um discurso com interesse em correção moral, necessariamente possui interesse em autonomia, de forma que existe uma relação intrínseca entre correção moral e o princípio da autonomia. ${ }^{64}$ Correção moral pressupõe assim autonomia.

Da afirmação da necessidade do regramento jurídico formal dos direitos

\footnotetext{
${ }^{61}$ ALEXY, Robert. Teoría del discurso y derechos humanos. Bogotá: UEC, 2001, p. 99.

62 Ibidem. 103/104.

63 Ibidem, pp. 103/104.

${ }^{64}$ Ibidem, p. 105.
} 
e da observância do princípio da autonomia individual como justificação destes direitos, decorre a existência de um direito geral à autonomia, representante dos direitos humanos e fundamentais mais gerais, que pode também ser rotulado de um "direito de liberdade geral" e ser assim formulado: "Cada um tem o direito de julgar livremente o que é conveniente e o que é bom e agir em consequência" ${ }^{65}$ Os direitos humanos, segundo este direito à autonomia individual, legitimar-se-ia na liberdade individual de escolhas existenciais e de projetos de vida.

Porém, como adverte Alexy, este direito individual não é ilimitado, mas vale prima facie; possui então estrutura de princípio, legitimando-se no jogo de ponderação com a autonomia dos outros, e também com bens coletivos. Neste último caso, a autonomia teria uma prevalência prima facie em relação aos bens coletivos, ou seja, no discurso de legitimação intermediado pelo princípio da ponderação, há uma carga de argumentação favorável à autonomia e desfavorável em relação aos bens coletivos. ${ }^{66}$

Os direitos se justificam como fundamentais se protegerem e possibilitarem o exercício da autonomia tanto privada como pública. Daí que, a partir do direito geral à autonomia, será construído o catálogo de direitos humanos e fundamentais. Para tanto, duas operações são praticadas: (i) em uma primeira operação, um direito concreto é deduzido diretamente da autonomia, como um caso especial da autonomia, conceitualmente contido nesta: são os casos, v.g., do exercício da liberdade religiosa, relativo à autonomia privada, e do exercício da liberdade de opinião, relativo à autonomia pública; (ii) em uma segunda operação, os direitos são justificados como fundamentais se atuam como "meios necessários" para o indivíduo atuar autonomamente: é o caso de direitos à proteção pelo Estado e o direito ao mínimo existencial ${ }^{67}$, aqui entendido como condição inicial da liberdade.

A construção doutrinária acima revela claramente que, para Alexy, os direitos sociais para além do mínimo existencial são indiretamente legitimados, portanto, apenas discursivamente possíveis e não necessários em sentido estrito, e por isso cabe exclusivamente à política de cada tempo o seu pleno desenvolvimento, ao passo que os direitos sociais contidos no âmbito de proteção do mínimo existencial seriam discursivamente necessários, não estando disponíveis às decisões políticas ordinárias e podendo ser judicialmente exigidos. ${ }^{68}$

\footnotetext{
${ }^{65}$ ALEXY, Robert. Teoría del discurso y derechos humanos. Bogotá: UEC, 2001, p. 111.

${ }^{66}$ Ibidem, p. 111.

${ }^{67}$ Ibidem, p. 112.

${ }^{68}$ No mesmo sentido, embora por fundamentações diversas, cf. TORRES, Ricardo Lobo. O Direito ao Mínimo Existencial. Rio de Janeiro: Renovar, 2009, pp. 113/137. Em construção doutrinária coerente com seus pressupostos ideológicos e todo o histórico estável de seu pensamento, Ricardo Lobo Torres defende que a jusfundamentalidade dos direitos sociais se reduz ao mínimo existencial, em seu duplo aspecto de proteção negativa contra a incidência de tributos sobre os direitos sociais mínimos de todas as pessoas e de proteção positiva consubstanciada na entrega de prestações estatais materiais em favor dos pobres. Por sua vez, os direitos sociais
} 


\section{b) $O$ argumento do consenso}

$\mathrm{O}$ argumento do consenso requer a aceitação universal do resultado discursivamente alcançado, ou seja, ele diz com concepções sobre resultados, se necessários ou impossíveis, dos discursos, de modo que, ainda que não implique em um sistema de direitos completamente fechado, conduz a algumas exigências de conteúdo e estrutura dos direitos humanos e fundamentais. Disso resulta um "paralelismo estrutural com o argumento da autonomia".

Segundo Alexy, o argumento de consenso complementa o de autonomia pela introdução da imparcialidade e então da igualdade. Segundo o argumento do consenso, todos têm o direito igual aos direitos humanos e fundamentais. ${ }^{70}$ A autonomia e os direitos corolários, já devidamente legitimados segundo o argumento da autonomia, encontrariam no argumento do consenso sua distribuição igualitária. Fundamentada a autonomia, pouco restaria para se chegar à igualdade, "pois entre autonomia e igualdade existe uma estreita relação": quem valora positivamente a autonomia (pública ou privada), valora negativamente a repartição desigual da autonomia. ${ }^{71}$ Dessa forma, da conexão dos argumentos de autonomia e consenso decorre que "basicamente só uma distribuição igual dos direitos humanos é um possível fruto de um discurso ideal". Conclusão distinta só seria válida se a repartição desigual se justificasse como meio de condução a uma maior autonomia para todos. ${ }^{72}$

Robert Alexy reconhece que o caráter idealístico do argumento do consenso, e do discurso de um modo geral, sugere significativas debilidades, vide a circunstância de só poder haver um "consenso hipotético", alcançável por pessoas reais sob condições ideais. Mas ainda que se considere o problema da idealização do discurso, é seguro afirmar que um resultado necessário do discurso é aquele que garante a todos o igual gozo a um sistema básico de direitos, ao passo que é um resultado impossível aquele que resulte na negação desta igualdade de direitos. ${ }^{73}$

Importante ainda destacar que mesmo o caráter ideal do discurso não permite, em matéria de diretos humanos, que os interlocutores levantem argumentos que não sejam demonstráveis, como aqueles metafísicos ou vinculados a doutrinas religiosas abrangentes. Estas espécies de argumentos não devem possuir qualquer peso na argumentação, justamente para que se assegure a racionalidade e imparcialidade do discurso. ${ }^{74} \mathrm{Em}$ suma, com

máximos, para além da esfera do mínimo existencial, devem ser obtidos na via do exercício da cidadania reivindicatória e da prática orçamentária, por meio do processo democrático. Esse é o caminho que levaria à superação da tese do primado dos direitos sociais sobre os direitos da liberdade, que inviabilizou o Estado Social de Direito, e da confusão entre direitos fundamentais e direitos sociais, que não permite a eficácia destes últimos sequer na sua dimensão mínima.

${ }^{69}$ ALEXY, Robert. Teoría del discurso y derechos humanos. Bogotá: UEC, 2001, p. 114.

${ }^{70}$ ALEXY, Robert. Teoría del discurso y derechos humanos. Bogotá: UEC, 2001, p. 116.

${ }^{71}$ Ibidem, pp. 126/127.

72 Ibidem, p. 127.

73 Ibidem, p. 117.

${ }^{74}$ Ibidem, p. 121. 
o argumento do consenso, a universalidade, em forma de igualdade e imparcialidade, se junta à autonomia e completa assim a base da concepção liberal dos direitos humanos: universalidade-autonomia.

\section{c) $\mathbf{O}$ argumento da democracia} premissas $^{75}$ :

Robert Alexy afirma que o argumento da democracia se compõe de três

(I) a primeira diz que o princípio do discurso, como ideal regulativo, só pode realizar-se aproximadamente através da institucionalização jurídica de procedimentos democráticos de formação da opinião e da vontade; ${ }^{76}$

(II) a segunda premissa expressa que as exigências da racionalidade discursiva podem realizar-se aproximadamente apenas em uma democracia em que os direitos políticos são fundamentais e podem ser exercidos com suficiente igualdade de oportunidades; ${ }^{77}$

(III) a terceira premissa diz que o exercício dos direitos políticos fundamentais e os direitos humanos com suficiente igualdade de oportunidades pressupõe o gozo de alguns direitos fundamentais não-políticos, como o direito à vida, ao mínimo existencial e a uma educação básica. ${ }^{78}$

Partindo destas três premissas, Alexy afirma a conexão necessária entre pretensão de correção moral, democracia e direitos fundamentais. Com o argumento da democracia, completando sua teoria da legitimação discursiva dos direitos humanos como legitimação inclusiva de direitos, ele evidencia que sua proposta não serve apenas como justificação da esfera de fundamentalidade dos direitos humanos, mas que "se evidencia também como teoria básica do Estado constitucional e democrático"79, em que os direitos fundamentais e democracia, apesar de todas as tensões, entram em uma inseparável associação.

Em síntese, esta é a formulação teórica de Alexy para a justificação dos direitos humanos por meio do discurso: o autor procurou fixar critérios objetivos para identificação de quais direitos seriam fundamentais e, portanto, excluídos do campo de decisão da política diária, e quais direitos têm sua realização dependente das decisões políticas de cada tempo; e o autor construiu estes critérios tendo em vista a ideia inclusiva de discurso, mas

\footnotetext{
${ }^{75}$ Ibidem, pp. 129/130.

${ }^{76}$ Ibidem, p. 129: "Se na realidade é possível uma aproximação à correção e legitimidade, isto só é possível na democracia".

77 Cf. ELY, John Hart. Democracy and Distrust. A Theory of Judicial Review. Cambridge: Harvard University Press, 1980: o autor elaborou uma teoria do controle de constitucionalidade das leis no sistema norte-americano que denominou de teoria do reforço representativo (representation-reinforcing theory) e que propunha que a Suprema Corte agiria legitimamente apenas quando interpretasse a Constituição de modo a assegurar a igualdade de representação popular no processo político e, por conseguinte, reforçar o processo democrático e o autogoverno pelo povo.

${ }_{78}$ ALEXY, Robert. Teoría del discurso y derechos humanos. Bogotá: UEC, 2001, p. 131.

${ }^{79}$ Ibidem, p. 131.
} 
não diretamente das regras procedimentais do discurso, mas sim de princípios que asseguram a participação livre e igual de todos - a autonomia, o consenso e a democracia. São fundamentais os direitos que asseguram às pessoas a tomada autônoma de decisões essenciais para as suas vidas, assim como a participação livre e igual na construção da vontade do Estado.

\subsection{Discursos de Legitimação e de Aplicação - a disputa entre Robert Alexy e Klaus Günther ${ }^{80}$}

A teoria do discurso alexyana não é isenta de críticas, e pensamos ser importante aqui apresentar ao menos uma delas. Nossa escolha foi pela abordagem feita por Klaus Günther, que incisivamente tenta desqualificar a tese do discurso jurídico de Alexy como discurso prático geral, o que importaria em desqualificar a teoria do discurso alexyana como inserida no contexto de renovação da razão prática.

\subsubsection{A tese alexyana do discurso jurídico como caso especial do discurso prático geral}

Como vimos, o caráter ideal da legitimação dos direitos humanos pelo discurso gera a necessidade do Direito, da institucionalização pelo Direito. Por sua vez, não é qualquer sistema jurídico que possa ser justificado sob as bases de um discurso racional orientado pelos ideais kantianos de universalidade e autonomia, mas somente aquele que preencha as elementares exigências da razão prática.

Uma institucionalização conforme os critérios da teoria do discurso incluem a preservação das garantias dos direitos humanos fundamentais e a institucionalização de procedimentos democráticos conforme o Estado de direito. Sendo assim, a passagem à positivação da pretensão de realização da razão prática pode gerar uma tensão entre autoridade e correção moral, entre segurança jurídica e justiça; a opção pela autoridade do Direito positivo permite que se considere, nestes casos, uma primazia apenas prima facie dos elementos institucionais sobre os de correção moral ${ }^{81}$, podendo os últimos, em casos concretos, prevalecer, sob pena de se abrir mão novamente da conexão necessária entre legalidade e legitimidade.

Segundo Alexy, "o fato de que argumentos institucionais só gozem de uma prevalência prima facie significa que a argumentação jurídica, ainda quando argumentos institucionais conduzam a um resultado determinado, segue dependendo de argumentos substanciais e prático-gerais". Esta circunstância

\footnotetext{
${ }^{80}$ Alguns autores já se debruçaram com muita competência sobre o tema: DWARS, Ingrid. Application Discourse and the Special Case-Thesis. Ratio Juris 5 (1), 1992, pp. 67/78; FERREIRA, Fernando Galvão de Andréa. O Discurso Jurídico como Discurso Prático: Aspectos do Debate entre Robert Alexy e Jürgen Habermas. Revista da Faculdade de Direito de Campos, ano VII, $\mathrm{n}^{\circ} 9$, 2006, pp. 85/101; BUSTAMENTE, Thomas da Rosa de. Sobre a justificação e a aplicação de normas jurídicas. Análise das críticas de Klaus Günther e Jürgen Habermas à teoria dos princípios de Robert Alexy. Revista de Informação Legislativa, ano 43, n 171, 2006, pp. 81/90; STRECK, Lenio Luiz. Verdade e Consenso. 2. ed. Rio de Janeiro: Lumen Juris, 2008, pp. 63/92.

${ }^{81}$ ALEXY, Robert. Teoría del discurso y derechos humanos. Bogotá: UEC, 2001, pp. 58.
} 
revela-se presente no caso das decisões judiciais que envolvam ponderação entre princípios opostos. ${ }^{82}$

Com esta conexão entre argumentos institucionais e argumentos práticogerais, inclusive morais, Alexy justifica sua tese de que a argumentação jurídica, e notadamente o discurso judicial, é um caso especial do discurso prático geral, ou seja, um caso especial de discussão racional sobre problemas práticos com pretensão de formular proposições normativas moralmente corretas. O discurso jurídico, também voltado para a discussão de questões práticas éticas e morais, seria um modelo especial do discurso prático, diferenciado em razão das condições limitadoras próprias das discussões que se desenvolvem no âmbito judicial.

Sua tese se justificaria então na medida em que (1) as discussões jurídicas se referem a questões práticas (questões sobre o que se deve fazer ou não fazer, ou sobre o que se pode fazer ou não fazer), e em que (2) ambos os discursos tratam da correção moral dos enunciados normativos (respectivamente, dos enunciados normativos jurídicos e dos enunciados normativos práticos). ${ }^{83} \mathrm{~A}(3)$ especialidade do discurso jurídico seria por conta de suas condições limitadoras próprias. ${ }^{84}$

(1) É certo que há muitas discussões que se referem a questões jurídicas e outras que não se trata de fundamentação de enunciados normativos. Porém, ao lado destas atividades, destaca-se a argumentação jurídica referida à solução de questões práticas, que cumpre um papel central não só na práxis, mas também na ciência jurídica. ${ }^{85}$

(2) Quanto à pretensão de correção, Alexy afirma que esta se apresenta distinta em cada discurso. No discurso jurídico, a preocupação não seria com a racionalidade absoluta da proposição normativa, mas com a racionalidade do enunciado normativo fundamentada em um ordenamento jurídico válido. ${ }^{86}$

(3) As soluções limitativas da argumentação jurídica não a desqualificariam como discurso prático, sem embargo, apenas a tornam um caso especial do discurso prático geral. ${ }^{87}$

$\mathrm{O}$ argumento alexyano de que o discurso jurídico também envolve questões de justiça, portanto, questões morais, e assim ostentam uma pretensão de correção moral, seria particularmente importante para os

\footnotetext{
82 Ibidem, pp. 58/59.

${ }^{83}$ ALEXY, Robert. Teoria de la argumentación jurídica. 2. ed. Madrid: CEPC, 2007, p. 207.

${ }^{84}$ Ibidem, p. 38: "Já se mencionou que o discurso jurídico se diferencia do discurso prático geral em que sua liberdade está limitada, em poucas palavras, pela lei, o precedente, a dogmática, e - no caso do processo - pelas leis procedimentais."

${ }^{85}$ Ibidem, p. 207.

${ }^{86}$ Ibidem, p. 208.

${ }^{87}$ Ibidem, p. 212: "O que se toma como referência é este tipo de argumentação que tem lugar sob estas condições limitativas, porém que, sem embargo, é uma argumentação racional. Esta referência à argumentação racional não só justifica, senão que faz que pareça necessário falar de discurso jurídico, embora não desapareçam as condições limitativas".
} 
chamados hard cases, em que autênticos dilemas morais só podem (e devem) ser solucionados institucionalmente por meio de argumentos carregados de conteúdo moral. Nestes casos, não conta apenas a autoridade do Direito, mas também argumentos de razão prática geral. Nestes casos, as decisões judiciais são espécies do discurso prático geral.

Nada obstante, esta construção teórica de Alexy é duramente criticada por Günther.

3.4.2. A crítica de Klaus Günther: discursos de legitimação e de aplicação

Klaus Günther pretende atacar a tese de Alexy de que a argumentação jurídica é um caso especial do discurso prático geral ${ }^{88}$. Para este outro professor alemão, a argumentação jurídica não seria um caso especial do discurso prático geral como defende Alexy, mas apenas um caso especial do discurso moral de aplicação. Para tanto, o professor parte da distinção que faz entre discurso de justificação e discurso de aplicação.

Günther defende a ideia da dependência normativa do Direito em relação à Moral, cabendo a esta a tarefa de fundamentar a validade das normas de conduta, e ao Direito a tarefa de aplicação destas normas válidas. Daí que em Günther não é possível afastar-se da razão prática, pois a racionalidade das normas jurídicas seriam diretamente deduzidas das normas morais conforme a estrutura prescritiva da razão prática. ${ }^{89}$ Segundo Günther, não basta seguir princípios corretos nos casos práticos, senão também deve sua aplicação imparcial atender a todas as circunstâncias especiais de cada caso, algo como um sentido aplicativo da imparcialidade, de modo que não se pode abandonar o emprego da razão prática nas situações de aplicação das normas. Este é o sentido do princípio da adequação que deve governar a aplicação das normas moralmente fundadas.

Levando em conta a separação entre as ações de justificar - fundamentar a validade - e aplicar - efetivar as normas válidas -, e uma vez pautado na diferença dos critérios que servem para esclarecer a validez de uma norma e para avaliar a adequação desta norma a uma situação concreta, Klaus Günther propôs dois níveis distintos do discurso prático geral:

a) discurso de justificação (Begründungsdiskurs) - por meio do qual se justifica a validade de uma norma conforme o princípio da universalidade, ou seja, da exigência de participação livre e igual dos interlocutores;

\footnotetext{
${ }^{88}$ GÜNTHER, Klaus. Teoria da Argumentação no Direito e na Moral: Justificação e Aplicação. São Paulo: Landy, 2004, p. 75 e ss.; Idem. Un Concepto Normativo de Coherencia para uma Teoría de la Argumentación Jurídica. Doxa 17-18, 1995, pp. 296 e ss.; Idem. Critical Remarks on Robert Alexy's 'Special-Case Thesis'. Ratio Juris 6 (2), 1993. A proposta de Günther tem amplo apoio de Habermas: HABERMAS, Jürgen. Facticidad y Validez. 4. ed., Madrid: Trotta, 2005, pp. 287/293.

${ }^{89}$ GÜNTHER, Klaus. Teoria da Argumentação no Direito e na Moral: Justificação e Aplicação. São Paulo: Landy, 2004, p. 11.
} 
b) discurso de aplicação (Anwendungsdiskurs) - por meio do qual se justifica a adequabilidade (Angemessenheit) da aplicação de uma norma em um caso concreto conforme o princípio da imparcialidade, ou seja, conforme a exigência de se tomar em consideração todas as características da situação que são relevantes para a aplicação coerente da norma e a relação desta norma com todas as demais normas válidas e aplicáveis prima facie. ${ }^{90}$

Sua pretensão ao separar estes dois níveis de discurso é a de deixar bem clara a distinção entre a justificação da validez de uma norma, tarefa da Moral, e a da aplicação de uma norma válida, tarefa do Direito. Partindo da ideia de que a distinção entre regras e princípios diz respeito à aplicação imparcial das normas em situações concretas, e não à estrutura das normas, Günther defende a ocorrência de diferentes comportamentos de colisão: (I) no caso de princípios, haveria um comportamento colisivo na dimensão da fundamentação da validade das normas jurídicas (colisão interna), de modo que o discurso de justificação teria por objeto a validade de cada norma e seria voltado para a generalizabilidade e universalizabilidade das normas, atuando então para a definição de quais normas seriam aplicáveis prima facie (válidas); (II) no caso das regras, haveria um comportamento colisivo na dimensão da aplicação das normas (colisão externa), de modo que o discurso de aplicação, sem que haja qualquer disputa acerca da validade da norma, teria por objeto a aplicação imparcial das normas julgadas válidas, consideradas todas as circunstâncias características do caso. ${ }^{91}$

Dizer que uma norma é válida e, portanto, aplicável prima facie, é tarefa de um discurso de legitimação; mas dizer que esta norma válida é definitivamente aplicável a um caso concreto, tendo em vista todas as circunstâncias do caso e a relação desta norma com outras normas válidas aplicáveis prima facie, é tarefa de um novo discurso, o discurso de aplicação. ${ }^{92}$ Sem embargo, a fundamentação da validez de uma norma, mesmo com a observância do princípio da universalidade, não é garantia de que ela será aplicada, daí a importância da distinção de níveis do discurso: as normas válidas são apenas prima facie aplicáveis, porque pode haver uma colisão externa entre normas igualmente válidas que poderiam ser aplicadas ao mesmo caso concreto. ${ }^{93}$

Günther chama a atenção para o fato de que esta distinção só não ocorreria diante de uma norma perfeita. No contexto ideal de uma norma perfeita, o discurso de fundamentação, por si só, em razão do participante prever todas as situações possíveis de aplicação da norma, abarcaria também o momento aplicativo, de modo que a "aplicação" da norma

${ }^{90}$ GÜNTHER, Klaus. Un Concepto Normativo de Coherencia para uma Teoría de la Argumentación Jurídica. Doxa 17-18, 1995, pp. 282/283.

${ }^{91}$ GÜNTHER, Klaus. Un Concepto Normativo de Coherencia para uma Teoría de la Argumentación Jurídica. Doxa 17-18, 1995, pp. 280/281.

${ }_{92}$ Ibidem, p. 283.

${ }^{93}$ Ibidem, p. 283. 
pertenceria ao momento da "validez". ${ }^{94}$ Mas, nos casos reais, nos casos de colisão normativa no caso concreto, deve-se identificar qual seria a norma adequada por meio de um discurso de aplicação.

Günther nega correção ao uso da ponderação, e afirma que para se julgar a adequação da norma válida ao caso concreto deve ser realizada uma completa descrição da situação, levando-se em conta todas as normas possivelmente aplicáveis (válidas, segundo o discurso de legitimação), de modo que se possa assim construir uma norma de decisão imparcial. Esta prática coerente de descrição completa de fatos e de relação destes com todas as normas válidas aplicáveis à situação é levada a efeito no nível do discurso de aplicação. No discurso de aplicação, as normas válidas, segundo o resultado de um discurso de justificação, possuem só o status de razões prima facie para a justificação de enunciados normativos particulares. Os participantes no discurso apenas sabem quais razões são definitivas depois de terem aduzido todas as razões prima facie relevantes sob a base de uma descrição completa da situação. Neste momento, não se trata mais de validez das normas em colisão, senão da adequação de uma delas sob a consideração de todas as circunstâncias da situação. ${ }^{5}$

O princípio de imparcialidade cumpre assim papel fundamental na teoria do discurso de Günther, seja na exigência de universalidade da norma como critério de uma fundamentação de validade imparcial, seja na aplicação da norma (válida) adequada a um caso concreto depois de consideradas todas as situações pertinentes como critério de construção imparcial da norma de decisão.

A partir das bases de sua Teoria do Discurso, como acima exposto de modo sucinto, Günther ataca a teoria de Robert Alexy de que a argumentação jurídica é um caso especial do discurso prático geral. Segundo Günther, a tarefa dos juristas seria tipicamente a de definição da norma válida adequada ao caso concreto, ou seja, a tarefa de aplicação. O discurso jurídico seria então um discurso de aplicação. Günther afirma que a "pretensão de correção" não pode governar a argumentação jurídica. Todo enunciado normativo possui uma pretensão de correção, no sentido de poder ter sua validade justificada argumentativamente em um discurso governado pelo princípio da universalidade. Portanto, a pretensão de correção diz com a validade do enunciado normativo, e esta validade deve ser aferida em um discurso de justificação, e apenas pressuposta em um discurso de aplicação. ${ }^{96}$

Alexy, como vimos ${ }^{97}$, defende que em um discurso jurídico procura-se justificar uma norma dentro dos limites de uma ordem legal válida, e é daí

\footnotetext{
94 Ibidem, p. 279.

95 Ibidem, p. 283.

96 GÜNTHER, Klaus. Un Concepto Normativo de Coherencia para uma Teoría de la Argumentación Jurídica. Doxa 17-18, 1995, p. 297.

${ }^{97}$ Cf. nota 87.
}

DiReITOS FundamentaIS $\mathcal{E}$ JUSTIÇA N 14 - JAN./MAR. 2011 
que surge a indagação crítica de Günther: "como se pode justificar a validade de uma norma, se ao mesmo tempo esta validade é pressuposta?" Günther conclui que o elemento essencial de um discurso de justificação, que é a possibilidade de se questionar a validade de uma norma - segundo o princípio da universalidade - está excluído da argumentação jurídica, já que nesta espécie de discurso a validade é pressuposta. E se a argumentação jurídica não pode referir-se à validade das normas, então não diz com uma pretensão de correção defendível em um discurso de fundamentação, o que descaracterizaria o discurso jurídico como espécie do discurso prático geral. Segundo Günther, se Alexy procura justificar seus argumentos jurídicos dentro de um determinado sistema de Direito válido, isso excluiria a possibilidade de uma justificação universal, e assim dificultaria a caracterização do discurso jurídico como caso especial do discurso prático geral. ${ }^{98}$

Em suma, para Günther, a argumentação jurídica não pode ser considerada um discurso de justificação, mas sim um discurso de aplicação, nada dizendo com a pretensão de correção, haja vista esta ser pressuposta em razão da afirmação da validade do sistema de Direito. Sendo assim, Günther afasta a ideia de que a argumentação jurídica é um caso especial do discurso prático geral, e afirma que a mesma é um caso especial do discurso moral de aplicação.

\subsubsection{A réplica de Robert Alexy}

Robert Alexy contesta as críticas de Günther afirmando que não se pode contrastar discurso de aplicação de discurso de justificação como duas formas independentes de discurso, haja vista qualquer discurso de aplicação incluir um discurso de justificação da qual seu resultado depende como consequência natural de uma prática decisória de teor universalista. ${ }^{99}$ Ele reconhece que existem dimensões de justificação e aplicação, mas aglutina estas dimensões em uma forma discursiva única: o discurso de aplicação. $\mathrm{Na}$ aplicação estaria embutida a justificação logicamente pressuposta, algo como inerente. Afastada a distinção metodológica entre os dois níveis de discurso, restaria refutada a objeção de Günther à tese do discurso jurídico como caso especial do discurso prático geral.

Robert Alexy defende que a tese da separação de Günther causa danos à racionalidade prática com o perigo de uma práxis decisória não universalista, não sendo então a melhor defesa de uma interpretação teorético-discursiva e, portanto, universalista, da imparcialidade na aplicação das normas. Não sendo possível uma prática universalista de decisões com a construção güntheriana, a demanda moral fundamental de igual tratamento permanece vazia diante do universo normativo esparsamente fornecido por esta metodologia. A relação entre o nível das normas válidas aplicáveis

${ }^{98}$ GÜNTHER, Klaus. Un Concepto Normativo de Coherencia para uma Teoría de la Argumentación Jurídica. Doxa 17-18, 1995, p. 298.

${ }^{99}$ ALEXY, Robert. Justification and Application of Norms. Ratio Juris 6 (2), 1993, p. 169. 
prima facie (discurso de justificação) e o nível das decisões definitivas o das normas adequadas (discurso de aplicação) - teria um caráter casuístico (ad hoc), com normas individuais definitivas feitas exclusivamente para casos individuais específicos e normas prima facie que deveriam ser avaliadas de maneiras diversas para cada nova situação. Em tal sistema de rígida distinção metodológica entre as duas formas de discurso, não seria possível alcançar a (desejada e) necessária coerência normativa. ${ }^{100}$

Outra objeção de Alexy é a de que na fórmula de aplicação de Günther inclui-se, na realidade, também uma justificação. A norma que se constrói em razão das variantes do caso concreto poderia ser construída ao nível das normas válidas aplicáveis prima facie, o que tornaria débil a distinção em dois níveis de discurso. ${ }^{101}$ Ademais, segundo Alexy, a tese que Günther formula acerca da coerência como princípio que governa o discurso de aplicação tornaria o discurso de justificação um mero discurso de topoi. ${ }^{102}$

Enfim, Alexy afirma que o fato de haver objetos distintos para os discursos de justificação e de aplicação - para o primeiro, julgar qual(is) norma(s) universal(is) é(são) válida(s), e para o segundo, julgar qual norma válida é adequada para uma certa situação - não conduz à circunstância de existirem duas espécies essencialmente diferentes de discurso, mas sim que existem duas diferentes operações dentro de uma forma única de discurso, ou seja, duas variações da mesma forma de discurso. ${ }^{103}$

\section{PRINCÍPIOS DE LEGITIMAÇÃO E PONDERAÇÃO}

\section{Características}

A legitimação discursiva dos direitos humanos, cujos contornos alexyianos foram descritos acima, é possível pela intermediação dos princípios formais, que deixam de atuar apenas no momento aplicativo das normas para se afirmarem como instrumentos de julgamento de validade normativa, de legitimação dos outros princípios. São princípios que não possuem conteúdo próprio, mas que cumprem a função de harmonizar e equilibrar a tensão que existe entre os diversos princípios materiais da ordem constitucional brasileira. ${ }^{104}$

Vazios de conteúdo, estes princípios desempenham papel fundamental na legitimação do ordenamento e dos direitos como medida de equilíbrio e dosagem entre os princípios fundamentais. O princípio da igualdade, por exemplo, sem conteúdo próprio, permite o equilíbrio entre os princípios fundamentais, daí se falar em igual liberdade, igual dignidade, etc., em suma, em igualdade de direitos.

\footnotetext{
${ }^{100}$ ALEXY, Robert. Justification and Application of Norms. Ratio Juris 6 (2), 1993, p. 163.

${ }^{101}$ Ibidem, pp. 164/165.

${ }^{102}$ Ibidem, p. 166.

${ }^{103}$ Ibidem, p. 167.

104 TORRES, Ricardo Lobo. A Legitimação dos Direitos Humanos e os Princípios da Ponderação e da Razoabilidade. In: TORRES, Ricardo Lobo (org.) Legitimação dos Direitos Humanos. 2. ed., Rio de Janeiro: Renovar, 2002, pp. 467/468, 491, 502.
} 
Mesmo em sua dimensão abstrata, os princípios fundamentais do art. $1^{\circ}$ da CF/88, por exemplo, podem parecer conflituosos, como a soberania e a dignidade da pessoa humana; como não existe princípio absoluto, se faz necessário determinar o equilíbrio entre estes princípios, o que se alcança com a intermediação de princípios formais como a ponderação, a igualdade, a razoabilidade, a coerência e a transparência.

\section{Princípios de legitimação e princípios de aplicação}

Estes princípios podem também apresentar-se como princípios de aplicação, o que ocorre quando são utilizados nos casos de colisão de bens e interesses em um caso concreto, onde se fazem necessários o equilíbrio e a harmonia entre estes bens e interesses. Neste caso, os princípios de aplicação atuam como normas que justificarão a aplicação das outras normas em colisão no caso concreto. Como afirma Humberto Ávila ${ }^{105}$, os princípios de aplicação, aos quais denomina postulados normativos aplicativos, funcionam como estrutura para aplicação de outras normas.

\section{Ponderação de princípios e princípio da ponderação}

Contudo, diante das limitações de espaço e de tempo, presentes em maior ou menor medida em toda e qualquer produção acadêmica, nos limitaremos a tratar do princípio da ponderação como princípio formal a ser utilizado no processo de legitimação dos direitos humanos e fundamentais, não obstante a importância de princípios como a razoabilidade e a igualdade.

\subsection{A trajetória da ponderação}

A ponderação surge como ponderação de interesses e bens no processo de aplicação do direito ${ }^{106}$ como oposição à esterilidade do modelo de subsunção para a solução de casos mais complexos. Nas sociedades complexas e pluralistas, é comum que surjam conflitos concretos entre direitos e posições igualmente privilegiados pelo ordenamento constitucional, de modo que a solução do conflito não se encontra pronta e acabada neste ordenamento, facilmente identificável por meio de uma subsunção, mas sim, que deverá ser construída pelo intérprete aplicador levando em conta os interesses em jogo, as circunstâncias de fato, sendo determinado, no caso concreto, o peso maior ou menor de cada princípio que representa cada direito, cada posição fundamental, vindo então a formular a decisão do caso concreto. A este trabalho de considerar direitos e interesses em conflito, e sopesar princípios, dá-se o nome de ponderação de princípios.

A toda evidência que a ponderação pressupõe a ideia alexyana de direitos fundamentais como princípios, e princípios como ordens de otimização, ou seja, que comportam aplicação gradual, de modo que o direito, em cada caso concreto, seja realizado na maior medida possível, considerando todas

\footnotetext{
105 ÁVILA, Humberto. Teoria dos Princípios. 3. ed., São Paulo: Malheiros, 2004, p. 89.

106 TORRES, Ricardo Lobo. Da Ponderação de Interesses ao Princípio da Ponderação. In: ZILLES, Urbano (coord.). Miguel Reale. Estudos em homenagem a seus 90 anos. Porto Alegre: EDIPUCRS, 2000, p. 643.
} 
as circunstâncias do caso e, em especial, os outros direitos e interesses contrapostos. A ponderação, em um sentido inicial, "pode [então] ser definida, de forma esquemática, como a técnica de decisão pela qual o operador jurídico contrapesa, a partir de um juízo dialético, os bens e interesses juridicamente protegidos que se mostrem inconciliáveis no caso concreto, visando determinar qual deles possui maior peso e, assim, identificar a norma jurídica abstrata que há de prevalecer como fundamento da decisão adotada". ${ }^{107}$

A ponderação é feita com o auxílio do princípio formal da proporcionalidade e suas máximas parciais de adequação, necessidade e proporcionalidade em sentido estrito, esta última o próprio mandado de otimização. Neste sentido, a ponderação pode ser considerada como princípio aplicativo, ferramenta metodológica dos discursos de aplicação. Como princípio aplicativo, sugerimos o seguinte conceito de ponderação: a ponderação de bens e interesses, como técnica de interpretação e solução de conflitos entre normas, consiste na atividade de sopesamento de bens e interesses igualmente tutelados pela constituição, que se encontram em conflito no caso concreto, onde o intérprete, depois de identificadas as normas constitucionais aplicáveis, e de examinadas todas as circunstâncias concretas envolvidas, decidirá sobre a precedência circunstancial de um determinado bem ou interesse colidente, formulando assim a norma de decisão válida para o caso concreto que, eventualmente, servirá para casos futuros, desde que se repitam as mesmas circunstâncias fáticas e normativas do caso julgado.

Por sua vez, como leciona Ricardo Lobo $\operatorname{Torres}^{108}$, a ponderação evoluiu de método de sopesamento de bens e interesses no caso concreto à posição de princípio formal de legitimação, que cumpre a função de harmonizar e justificar princípios materiais no processo de criação e legitimação do Direito. Assim, a ponderação deixa de ser considerada apenas um princípio de aplicação, ou como quer Humberto Ávila, um postulado aplicativo, e passa também a cumprir a função de princípio de legitimação.

A ponderação deixa de habitar apenas os discursos de aplicação e passa a cumprir papel fundamental nos discursos de legitimação, servindo então de instrumento formal de acomodação de princípios conteudistas na fase de criação e justificação do direito. A ponderação evolui assim de ponderação de princípios para princípio de ponderação, princípio vazio de conteúdo que, ele próprio, não se abre para o jogo de ponderação. Daí se falar em Estado de Ponderação, representado pela busca da realização ótima da justiça, em sintonia com a democracia, por meio da ponderação e da proporcionalidade. Neste sentido é a lição de Ricardo Lobo Torres:

\footnotetext{
${ }^{107}$ PEREIRA, Jane Reis Gonçalves. Interpretação Constitucional e Direitos Fundamentais. Rio de Janeiro: Renovar, 2006, p. 220.

108 TORRES, Ricardo Lobo. Da Ponderação de Interesses ao Princípio da Ponderação. In: ZILLES, Urbano (coord.). Miguel Reale. Estudos em homenagem a seus 90 anos. Porto Alegre: EDIPUCRS, 2000, p. 643.
} 
"Sem jamais perder o vínculo com bens ou interesses eventualmente em jogo na aplicação do direito, a ponderação ganha dimensão mais ampla, para se caracterizar como princípio de legitimação de todos os outros princípios constitucionais, não só dos princípios fundantes do ordenamento jurídico (dignidade humana, soberania, cidadania, etc.), como dos princípios vinculados à liberdade, à segurança e à justiça, tornando-se modelo para as apreciações de lege ferenda."

Sem deixar de cumprir importante função nos discursos de aplicação e na solução de conflitos concretos, a ponderação passou também a servir aos discursos de legitimação, onde os princípios são sopesados em direção a futuras previsões legislativas. Esta nova faceta da ponderação nos permite falar em pré-ponderação, um modelo de ponderação que cumpre a função de "equilíbrio à elaboração da lei"110, que atua no momento de justificação dos direitos e do Direito, equilibrando e harmonizando a influência dos princípios materiais sobre a criação legislativa, atenuando as tensões abstratas entre justiça e segurança, direitos fundamentais e democracia.

Como afirma Lobo Torres, a ponderação deixa de se referir exclusivamente aos fatos colocados em julgamento para ganhar a estatura de uma ponderação lega ${ }^{111}$. A ponderação serviria para otimizar os valores que fundam nossa ordem constitucional e assim permitir a positivação equilibrada dos mesmos. Esta ponderação no estágio de legitimação dos direitos pode ser encontrada na acomodação hermenêutica entre os princípios fundantes do Estado brasileiro, previstos no art. $1^{\circ}$ da CF/88, como a dignidade humana e a soberania. Em matéria tributária a encontramos nas leis sobre substituição tributária, onde ocorre uma ponderação entre praticidade e eficiência da tributação, de um lado, e capacidade contributiva, de outro. Em matéria ambiental, a proteção do meio ambiente de um lado, a liberdade de exercício de atividades econômicas, de outro. A construção legislativa de políticas públicas e do orçamento são exemplos da necessidade do legislador ponderar valores e interesses em suas escolhas trágicas em um ambiente de recursos financeiros limitados. ${ }^{112}$

Estas pré-ponderações legislativas ficam, em um Estado de direito, sujeitas à revisão judicial que também utilizará da ponderação para afirmar a validade do resultado legislativo, onde de um lado estará o direito ou interesse preterido, e do outro, o direito ou interesse prestigiado juntamente com o princípio democrático.

\footnotetext{
109 Ibidem, p. 647.

110 TORRES, Ricardo Lobo. A Legitimação dos Direitos Humanos e os Princípios da Ponderação e da Razoabilidade. In: TORRES, Ricardo Lobo (org.) Legitimação dos Direitos Humanos. 2. ed., Rio de Janeiro: Renovar, 2002, p. 495.

${ }^{111}$ Ibidem, p. 496.

112 TORRES, Ricardo Lobo. O Direito ao Mínimo Existencial. Rio de Janeiro: Renovar, 2009, p. 169: "A ponderação tem grande importância para o planejamento estatal, para as políticas públicas e para as opções orçamentárias necessárias à otimização dos direitos sociais, o que caracteriza o Estado Ponderador."
} 


\subsection{Ponderação como parte da natureza do Direito}

Robert Alexy dá um passo mais adiante na construção teórica da ponderação. No âmbito de sua concepção dualista do Direito, o teórico alemão defende que a ponderação é "uma parte da natureza do direito", na medida em que cumpre um papel "não apenas na criação e aplicação do direito, ou seja, na prática jurídica, mas também no próprio fundamento do direito." ${ }^{113}$ Alexy avança assim no dimensionamento do papel da ponderação.

Este pensamento reafirma o papel legitimador da ponderação. Alexy recorda que a institucionalização do Direito não faz desaparecer a pretensão de correção moral, ou seja, a pretensão à justiça, que permanece viva por trás do e no Direito. Por esta razão, devem-se distinguir dois níveis de correção: a correção de primeira ordem e a de segunda ordem. ${ }^{114} \mathrm{~A}$ correção de primeira ordem refere-se apenas à dimensão ideal do Direito, é a pretensão à justiça. A correção de segunda ordem é mais abrangente, e refere-se tanto à dimensão ideal quanto a real, ou seja, alcança tanto a pretensão à justiça quanto à segurança jurídica.

Desse modo, a pretensão à correção, como pretensão de segunda ordem, necessariamente conecta tanto o princípio de justiça quanto a segurança jurídica com o Direito. A segurança jurídica exigindo, de um lado, comprometimento com as normas positivadas, e a justiça, de outro, exigindo que o resultado da institucionalização seja moralmente correta. Apontando para direções que podem circunstancialmente se opor, estes princípios podem então colidir, e frequentemente colidem entre si; mas, ao invés de um suplantar ao outro em todos os casos, é exigido, pelo caráter dualista do direito e a fim de alcançar a harmonia do sistema jurídico, que eles sejam concretizados em uma adequada proporção. Esta correta proporção é uma questão de ponderação. Desse modo, a pretensão de correção de segunda ordem, a do equilíbrio entre a dimensão ideal e a institucional do Direito, é alcançada com a intermediação da ponderação, e por isso ela seria princípio jurídico que faz parte da própria natureza do Direito. ${ }^{115}$

A tese de Alexy ratifica o papel da ponderação como princípio de legitimação, de aferição do alcance da pretensão de correção moral própria de toda proposição normativa. A ponderação seria então instrumento decisivo de aproximação da dimensão institucional do Direito à sua dimensão ideal, dimensão de justiça. A ponderação seria assim uma afirmação da concepção não positivista do Direito.

\subsection{Críticas à ponderação}

O uso da ponderação não é também isenta de críticas. Jürgen Habermas tem sido talvez o principal crítico da ponderação e da ideia dos direitos

\footnotetext{
${ }^{113}$ ALEXY, Robert. The Dual Nature of Law. Ratio Juris 23 (2), 2010, p. 174.

114 Ibidem, p. 174

115 ALEXY, Robert. The Dual Nature of Law. Ratio Juris 23 (2), 2010, p. 174: "This shows that balancing has a role to play not only in the creation and application of law, that is, in legal practice, but also at the very basis of law. It is a part of the nature of law."
} 
fundamentais formulados como princípios ${ }^{116}$, estando seu pensamento muito próximo das formulações da teoria interna dos limites dos direitos fundamentais. Habermas, focado na dimensão aplicativa da ponderação, afirma que o Tribunal Constitucional, ao sopesar valores quando da aplicação das normas constitucionais sobre direitos fundamentais acaba por ignorar a normatividade destes direitos e o que já estava previsto na própria Constituição, importando em decisionismo judicial e invasão da seara reservada ao jogo democrático. Desta forma, a ponderação seria uma fórmula irracional de interpretação utilizada pelo Tribunal Constitucional para tomar decisões arbitrárias e irracionais. Faltariam parâmetros racionais para o sopesamento, de modo que os direitos fundamentais correriam o risco de serem vítimas de "juízos irracionais". ${ }^{117}$ Para evitar o enfraquecimento dos direitos fundamentais em razão da irracionalidade da ponderação, Habermas propõe que se adote, para a solução de conflitos entre direitos fundamentais, a teoria da norma adequada, da lavra de seu discípulo Klaus Günther e anteriormente discutida. ${ }^{118}$

O maior ponto de crítica à ponderação reside então na cogitada atribuição excessiva de discricionariedade ao julgador no processo ponderativo, o que desbordaria na irracionalidade das decisões e na sua falta de legitimidade democrática. Acontece que estas críticas parecem desconhecer que a atividade do juiz, no âmbito da pura e simples subsunção de normas constitucionais abertas e indefinidas, pode revelar-se tanto ou mais criativa se comparada à atividade ponderativa. O uso exclusivo da subsunção, tributária dos métodos formalistas e mecanicistas próprios do positivismo formalista, não fornece maior segurança ou objetividade ao processo hermenêutico das normas constitucionais de direitos fundamentais. $\mathrm{Na}$ verdade, como observa a professora Jane Reis, "é preciso ter em conta que a ausência de objetividade integral não é uma característica que possa ser imputada apenas à metódica da ponderação, mas é algo que se apresenta sempre que é preciso decidir uma questão jurídica controvertida". ${ }^{11}$

Merece então destaque a advertência de Alexy no sentido de que uma teoria que leva a sério os direitos fundamentais como princípios não pode sustentar que a ponderação seja um procedimento que conduza, em todo e qualquer caso, a um resultado único e inequívoco. Na realidade, a teoria dos direitos fundamentais como princípios sustenta que, "embora o sopesamento nem sempre determine um resultado de forma racional, isso é em alguns casos possível, e o conjunto desses casos é interessante o suficiente para justificar o sopesamento como método." Alexy propõe, para se buscar esta racionalidade na maior medida possível, uma lei de sopesamento dividida em três partes: (i) primeiro, a avaliação do grau de não-satisfação, afetação

\footnotetext{
${ }^{116}$ HABERMAS, Jürgen. Facticidad y Validez. 4. ed., Madrid: Trotta, 2005, p. 326 e ss.

117 Ibidem, pp. 332/333.

118 Ibidem, pp. 289/290.

119 PEREIRA, Jane Reis Gonçalves. Interpretação Constitucional e Direitos Fundamentais. Rio de Janeiro: Renovar, 2006, p. 273.
} 
ou intervenção em um dos princípios; (ii) segundo, a avaliação da importância da satisfação do princípio colidente; (iii) por fim, a avaliação se a importância da satisfação do princípio colidente justifica a afetação ou a não-satisfação do outro princípio. ${ }^{120}$ Trata-se aqui de buscar juízos racionais sobre intensidades de intervenções e graus de importância e balancear estas grandezas de modo que se possa alcançar o resultado racional almejado. Alexy vai comparar graus de não-satisfação ou intervenção de um princípio, de um lado, e graus de importância do princípio colidente, do outro.

Estes graus de não-satisfação e intervenção podem ser leve, moderado e sério, e a partir do reconhecimento destes graus deve-se observar a seguinte equação: "quanto maior for o grau de não-satisfação ou de afetação de um princípio, tanto maior terá que ser a importância da satisfação do outro". ${ }^{121}$ Esta fórmula consiste na máxima da proporcionalidade em sentido estrito, que requer a otimização em relação aos princípios colidentes, o que não passa de sopesamento dos mesmos. No primeiro passo, o intérprete deve avaliar o grau de não-satisfação ou intervenção no princípio; depois, o grau de importância da satisfação do princípio colidente. De posse destas avaliações, o intérprete deve julgar, segundo os graus identificados, "se a importância do princípio colidente justifica a afetação ou a não-satisfação do outro princípio". ${ }^{122}$

Diante destas avaliações, o intérprete pode julgar justificada ou não a afetação de um princípio em favor do outro, como também pode modular a afetação de modo a melhor otimizar os princípios colidentes. E para produzir um resultado racionalmente controlável, estas avaliações devem ser realizadas por meio de uma argumentação jurídica que encerre uma decisão devidamente motivada, com a ponderação sendo plenamente demonstrada como um procedimento que revê explicitamente os três passos apontados por Alexy. Segundo este professor, as decisões ponderativas tornam-se dessa forma racionalmente demonstráveis e controláveis.

Sem embargo, as decisões judiciais baseadas nos juízos ponderativos não podem ser taxadas de irracionais porque a ponderação não apontaria a um único resultado possível, isto porque o raciocínio ponderativo não tem e nem pode ter a pretensão de oferecer uma única resposta correta ao julgamento dos casos difíceis, haja vista a possibilidade de mais de uma solução correta ser algo inerente à própria indeterminação do Direito, especialmente em se tratando de direitos fundamentais expressos em princípios e conceitos indeterminados. A pretensão do raciocínio ponderativo, metodologicamente estruturado na fórmula proposta por Alexy, é proporcionar a melhor resposta correta para a colisão concreta, o que deverá ser feito com o uso do princípio da proporcionalidade e por meio da demonstração racional e objetiva do balanceamento dos bens e interesses constitucionais colidentes, de forma

\footnotetext{
${ }^{120}$ ALEXY, Robert. Teoria dos Direitos Fundamentais. São Paulo: Malheiros, 2008, p. 594.

121 Ibidem, p. 593

122 Ibidem, p. 594
} 
que seja apontada, justificadamente, qual bem ou interesse deve prevalecer e em que medida o bem ou interesse contraposto deve ceder.

Diante da indeterminação semântica das normas constitucionais sobre direitos fundamentais e da necessidade de juízos valorativos, qualquer método de interpretação, além da ponderação, se mostrará incapaz de oferecer uma única solução possível aos conflitos entre estes diretos (colisões em sentido estrito) ou entre estes direitos e outros interesses constitucionalmente tutelados (colisões em sentido amplo) ${ }^{123}$. Contudo, a ponderação, com o auxílio de uma argumentação racional que procure descrever e justificar o procedimento e as razões do juízo ponderativo, apresenta, segundo pensamos, em relação aos demais métodos, maiores vantagens quanto à transparência das razões de construção da norma de decisão. O caráter criativo no juízo de ponderação fica à mostra por meio do desenvolvimento da argumentação jurídica racional, principalmente porque pautada no juízo de proporcionalidade, de modo que o raciocínio empreendido fica sujeito ao controle externo reconstrutivo de modo transparente e objetivo.

Em suma, se há um déficit de racionalidade e objetividade do juízo ponderativo, ele não é maior do que o dos métodos categorizantes, tendo a ponderação a vantagem de ser mais transparente na demonstração dos fundamentos da norma de decisão, permitindo o melhor controle da racionalidade das decisões. Por outro lado, a toda evidência que estas críticas são todas inseridas em um debate mais amplo, de natureza políticoinstitucional: o debate que defende menos Judiciário, e mais democracia. ${ }^{124}$

Tratar-se-ia, estas críticas, de rejeitar posturas criativas do intérprete judicial em favor de uma concepção excessivamente formalista do princípio democrático e de uma visão ortodoxa da separação de poderes, pugnando pelo uso dos métodos tradicionais da interpretação para a solução das diversas espécies de antinomias normativas, em especial da categorização e da subsunção, ainda que os tradicionais métodos de solução de antinomias se mostrem inoperantes para os casos constitucionais mais complexos e indefinidos. Mas, com efeito, estes riscos não significam que o juiz constitucional deva se comportar como mera arena homologatória das decisões legislativas prévias. A criação judicial do Direito, nos casos difíceis, acaba se apresentando como inevitável.

Todas estas críticas e preocupações conduzem à afirmação já feita neste trabalho, citando a Waldron: a de que qualquer teoria da justiça e dos direitos fundamentais não pode ignorar a necessidade de se formular uma teoria acerca da autoridade para tomar estas decisões. As preocupações

${ }^{123}$ Cf. PEREIRA, Jane Reis Gonçalves. Interpretação Constitucional e Direitos Fundamentais. Rio de Janeiro: Renovar, 2006, p. 269 e ss.

${ }^{124}$ Ibidem, p. 289: "o que realmente se encontra por trás das diversas críticas ao método ponderativo é a concepção de que o Judiciário é uma mera instância executória das decisões legislativas ou, em outros termos, a noção de que a atividade judicial consiste em desvendar e aplicar um julgamento que foi feito anteriormente pelo Parlamento". 
institucionais fazem parte do cenário de discussão sobre os processos de justificação e aplicação dos direitos fundamentais, que deve conviver com a democracia como valores igualmente valiosos do atual estágio de desenvolvimento não só do constitucionalismo, mas da própria sociedade. ${ }^{125}$ Mas, como já dissemos, isso é assunto que extrapola o espaço deste trabalho.

\section{CONCLUSÕES}

Nossa proposta aqui foi a de examinar a temática da legitimação dos direitos humanos por sua perspectiva estratégico-discursiva, notadamente na vertente alexyana, com o processo de justificação e aplicação destes direitos sendo intermediado pelos princípios vazios de legitimação e aplicação, em especial a ponderação. Trata-se, a toda evidência, de estratégia racional e condizente com o Estado democrático de direito e o seu elemento estruturante da democracia. Direitos fundamentais e democracia são assim bem equacionados na fórmula discursiva de legitimação destes direitos.

É de notar que o problema da justificação dos direitos projeta consequências importantes nas práticas institucionais de realização da vontade constitucional, que vão desembocar na eterna dificuldade de fixação das balizas do relacionamento entre Direito, Moral e Política. Assumimos aqui francamente a ideia de dependência do Direito em relação à Moral sob o ponto de vista da justificação dos direitos humanos, onde o Direito legitima-se por estes direitos, que, por sua vez, justificam-se em princípios morais. Em última instância, o Direito irá legitimar-se na Moral. E os valores morais da sociedade, que convivem em constante tensão dialética, podem se acomodar discursivamente, de modo que a solução das grandes questões práticas coletivas e individuais pode ser alcança por meio da estratégia discursiva de legitimação.

Por sua vez, é muito difícil afirmar uma separação rígida entre Direito e Política quando se trata de grandes questões constitucionais, ou seja, daqueles dilemas morais que podem ser classificados como casos difíceis. Grandes questões morais, verdadeiros empates morais, acabam reduzindo as diferenças entre Política e Direito, entre democracia e direitos fundamentais, entre os campos de atuação dos Poderes Legislativo e Judiciário. Sem embargo, quando se trata de discursos de legitimação dos direitos humanos, de afirmar a

${ }^{125}$ O próprio Robert Alexy, ainda dentro de sua proposta de legitimação discursiva dos direitos fundamentais, procura legitimar a atuação das Cortes Constitucionais a partir da formulação de uma teoria que ele denomina "constitucionalismo discursivo", que deriva da conexão entre cinco diferentes conceitos: (a) direitos constitucionais; (b) ponderação; (c) discurso; (d) controle de constitucionalidade; e (e) representação. O constitucionalismo discursivo seria uma fórmula de aproximação do constitucionalismo com a democracia sob a forma deliberativa. Utilizando esta fórmula, o autor procura justificar a legitimidade do controle de constitucionalidade com o uso da ponderação por meio do conceito de representação argumentativa. Alexy propõe que uma forma de conciliar a democracia com a revisão judicial da constitucionalidade das leis por Cortes Constitucionais é a de conceber estas Cortes também como "representantes do povo". Não um representante político, credenciado por votos e eleições, mas um "representante argumentativo", credenciado pela qualidade e aceitação do discurso, dos argumentos. (ALEXY, Robert. Balancing, constitutional review, and representation. International Journal of Constitutional Law (4), 2005, pp. 572/581). 
justificação da validade de práticas e normas tendo como parâmetros estes direitos, não é fácil definir a quem cabe desenvolver o discurso institucional que ao final deve prevalecer. É muito importante ter isso em mente, pois aqueles que criticam a legitimação pragmática realizada pelo Judiciário, principalmente por meio da ponderação, apóiam-se numa rígida distinção entre Direito, Moral e Política que, pensamos, nem sempre se mostra capaz de afirmar a ilegitimidade da atuação da instância judicial em matéria de direitos fundamentais. O importante nos parece é saber que os grandes dilemas morais não se resolvem pelo monólogo institucional, pela última palavra de instâncias hegemônicas, mas sim por meio de diálogos institucionais pautados pelos melhores argumentos e dirigidos à solução mais inclusiva possível.

\section{BIBLIOGRAFIA}

ALEXY, Robert. Teoría del discurso y derechos humanos. Bogotá: UEC, 2001. . The Dual Nature of Law. Ratio Juris 23 (2), 2010.

. A Discourse-Theoretical Conception of Pratical Reason. Ratio Juris 5 (3), 1992. . Teoria de la argumentación jurídica. 2. ed., Madrid: CEPC, 2007. . Justification and Application of Norms. Ratio Juris 6 (2), 1993.

. Balancing, constitutional review, and representation. International Journal of Constitutional Law (4), 2005.

ÁVILA, Humberto. Teoria dos Princípios. 3. ed., São Paulo: Malheiros, 2004.

BARROSO, Luís Roberto. Fundamentos Teóricos e Filosóficos do novo Direito Constitucional Brasileiro. In: Temas de Direito Constitucional. Tomo II. Rio de Janeiro: Renovar, 2003.

. Curso de Direito Constitucional Contemporâneo. São Paulo: Saraiva, 2009.

BOBBIO, Norberto. Presente y porvenir de los derechos humanos. In: Anuário de Derechos Humanos, vol. 1. Madrid: Universidad Complutense, 1981.

BONALDO, Frederico; BENEDUZI, Renato Resende. Razão Prática e Razão Teórica. (verbete) In: BARRETO, Vicente de Paulo. Dicionário de Filosofia do Direito. Rio de Janeiro: Renovar, 2006.

BUSTAMENTE, Thomas da Rosa de. Sobre a justificação e a aplicação de normas jurídicas. Análise das críticas de Klaus Günther e Jürgen Habermas à teoria dos princípios de Robert Alexy. Revista de Informação Legislativa, ano 43, nº 171, 2006.

CALSAMIGLIA, Albert. Postpositivismo. Doxa 21 - I, 1998.

D’ANREA, Luigi. Ragionevolezza e Legittimazione del Sistema. Milano: Giuffrè, 2005. DWARS, Ingrid. Application Discourse and the Special Case-Thesis. Ratio Juris 5 (1), 1992.

ELY, John Hart. Democracy and Distrust. A Theory of Judicial Review. Cambridge: Harvard University Press, 1980.

FERNANDEZ, Eusebio. Fundamento de los derechos humanos. In: Anuário de Derechos Humanos, vol. 1. Madrid: Universidad Complutense, 1981.

FERREIRA, Fernando Galvão de Andréa. O Discurso Jurídico como Discurso Prático: Aspectos do Debate entre Robert Alexy e Jürgen Habermas. Revista da Faculdade de Direito de Campos, ano VII, nº 9, 2006. 
GÜNTHER, Klaus. Teoria da Argumentação no Direito e na Moral: Justificação e Aplicação. São Paulo: Landy, 2004.

. Un Concepto Normativo de Coherencia para uma Teoría de la Argumentación Jurídica. Doxa 17-18, 1995.

Critical Remarks on Robert Alexy's 'Special-Case Thesis'. Ratio Juris 6 (2), 1993.

HABERMAS, Jürgen. Sobre a legitimação pelos Direitos Humanos. In: MERLE, Jean-Christophe; MOREIRA, Luiz (org.) Direito \& Legitimidade. São Paulo: Landy, 2003. Comentários à Ética do Discurso. Lisboa: Instituto Piaget, 1999.

. Facticidad y Validez. 4. ed., Madrid: Trotta, 2005.

LEAL, Rogério Gesta. Jürgen Habermas. (verbete) In: BARRETO, Vicente de Paulo. Dicionário de Filosofia do Direito. Rio de Janeiro: Renovar, 2006.

NIGRO, Rachel. A virada linguístico-pragmática e o pós-positivismo. Direito, Estado e Sociedade n. 34, 2009.

NINO, Carlos Santiago. La constitución de la democracia deliberativa. Barcelona: Gedisa, 2003.

. Introducción al Análisis del Derecho. 11. ed., Barcelona: Ariel, 2003.

. Ética y derechos humanos. Um ensayo de fundamentación. 2. ed., Buenos Aires: Astrea, 2007.

PEREIRA, Jane Reis Gonçalves. Interpretação Constitucional e Direitos Fundamentais. Rio de Janeiro: Renovar, 2006.

PÉREZ LUÑO, Antonio-Enrique. Derechos Humanos, Estado de Derecho y Constitución. 9. ed., Madrid: Tecnos, 2005.

RAWLS, John. La justicia como equidad. Uma reformulación. Barcelona: Paidós, 2002.

SARLET, Ingo Wolfgang. A Eficácia dos Direitos Fundamentais. 7. ed., Porto Alegre: Livraria do Advogado, 2007.

SEN, Amartya. Human rigths and the limits of the Law. Cardozo Law Review 27 (6), 2006.

SILVA, Alexandre Garrido da. Direitos Humanos, Constituição e Discurso de Legitimação: Possibilidades e Limites da Teoria do Discurso. In: TORRES, Ricardo Lobo (org.) Legitimação dos Direitos Humanos. 2. ed., 2002.

STRECK, Lenio Luiz. Verdade e Consenso. 2. ed., Rio de Janeiro: Lumen Juris, 2008.

TORRES, Ricardo Lobo. A Legitimação dos Direitos Humanos e os Princípios da Ponderação e da Razoabilidade. In: TORRES, Ricardo Lobo (org.) Legitimação dos Direitos Humanos. 2. ed., Rio de Janeiro: Renovar, 2002.

Da Ponderação de Interesses ao Princípio da Ponderação. In: ZILLES,

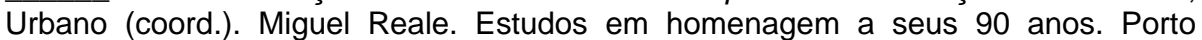
Alegre: EDIPUCRS, 2000.

. O Direito ao Mínimo Existencial. Rio de Janeiro: Renovar, 2009.

WALDRON, Jeremy. The Core of the Case Against Judicial Review. The Yale Law Journal 115 (6), 2006.

A Right-Based Critique of Constitutional Rights. Oxford Journal of Legal $\overline{\text { Studies }} 13$ (1), 1993.

Direitos Fundamentals E JUSTIÇA N 14 - JAN./MAR. 2011 